\title{
CARL MENGER AND THE SPANISH SCHOLASTICS
}

\author{
ELIAS HUBER*
}

Fecha de recepción: 18 de septiembre de 2015

Fecha de aceptación: 3 de octubre de 2016

Resumen: Este trabajo investiga si los escolásticos tardíos españoles influyeron en Carl Menger en términos de la historia de las ideas económicas. Se realizó una investigación por palabras clave de sus nombres en la literatura alemana, francesa e italiana que Menger cita en sus Principios. También se examinó la colección de Carl Menger y los escritos de Menger en búsqueda de referencias. Los resultados muestran que parece existir poca evidencia de una posible influencia.

Palabras clave: Carl Menger, escolásticos españoles, economía alemana, Principios de Economía, teoría subjetiva del valor.

Clasificación JEL: B1; B31, B53.

Abstract: This work investigates whether the Spanish late scholastics influenced Carl Menger in terms of the history of economic ideas. A key word research for their names was performed in the German, French and Italian literature which Menger cites in his Principles. The Carl Menger Collection and Menger's writings were also examined for references. Results show that there seems to be little evidence for an influence.

Keywords: Carl Menger, Spanish scholastics, School of Salamanca, German economics, Principles of Economics, subjective value theory.

JEL Codes: B1; B31, B53.

* Ph.D. candidate at King Juan Carlos University. The author wants to thank Professor Philipp Bagus under whose tutorship this work developed as a master thesis. Also he wants to thank Georg Bühler for his valuable help with some of the translations. Kristof Berking, Christian Schneider and two anonymous referees further provided helpful criticism. All mistakes remain with the author. 


\section{I \\ INTRODUCTION}

There is a growing consensus that Spanish late scholasticism anticipated some of the key insights of the Austrian school, especially on value theory (Hülsmann 2007, 112; Huerta de Soto 2008 [2000], 34; Rothbard 2006c [1976]). This standpoint often goes, however, hand in hand with another thesis. Because the Spanish scholastics had such a high level of knowledge, somehow -it is implicitly or explicitly assumed - they must have influenced subsequent economists, even Carl Menger himself. But this is an entirely different question because similarity of ideas does not imply transmission of these ideas. To make such a case is a very difficult endeavour. Menger wrote his Principles 250 years after Spanish scholasticism and could not communicate with our Spanish writers. He might have read all their books, nevertheless, a critic could reasonably argue that Menger discovered subjective value theory on his own. Even if Menger would cite the Spaniards a few times, he might just cite them for endorsement of his own ideas. The burden of proof becomes even higher if Menger does not refer to the Spanish scholastics. Now we have to look for a transmitter who is both influenced by the Spaniards and influences Menger. Either way, our research question is:

Did the Spanish late scholastics influence Carl Menger in terms of the history of ideas?

The usual way for a scientist to indicate intellectual debt is citation. Thus we performed a key word research for the names of the Spanish scholastics in the writings of German, French and Italian economists. Our research question is highly relevant. Not only because several think tanks in Spain appeal to Spanish scholasticism (Instituto Juan de Marina, Centro de Covarrubias), but also for Rothbard's revision in the history of ideas. According to this scholar, Adam Smith signified a regress in economics because he endorsed a more objective value theory (Rothbard 2006b [1995], xi). The Austrian tradition should therefore not be traced back to English classicism but to thinkers like Say, Galiani or the scholastics. 
The results are presented as follows: section two deals with ten Austrian ideas which were anticipated by the Spanish scholastics. Section three is about past findings concerning an influence. Section four looks for a direct link between Menger and the Spanish scholastics. Section five investigates whether the Spaniards influenced the German economists. Section six examines the role of Italian economics in transmitting the Spanish value doctrine. The central result is that there seems to be little evidence for an influence.

II TEN ANTICIPATIONS OF THE SPANISH SCHOLASTICS

It is the achievement of Professor Huerta de Soto to point out many of the intellectual accomplishments of the Spanish scholastics. In their writings, he detects ten «theoretical key principles of the Austrian school» (Huerta de Soto 2008 [2000], 33). These are: first, subjective value theory (Diego de Covarrubias y Leyva); second, the correct relationship between prices and costs (Luis Saravia de la Calle); third, the dynamic nature of the market and the impossibility of the model of equilibrium (Juan de Lugo, Juan de Salas); fourth, the dynamic concept of competition understood as a process of rivalry among sellers (Castillo de Bovadilla, Luis de Molina); fifth, the rediscovery of the time preference principle (Azpilcueta Navarro); sixth, the distorting influence of the inflationary growth of money on prices (Juan de Mariana, Diego de Covarrubias, Azpilcueta Navarro); seventh, the negative economic effects of fractional-reserve banking (Luis Saravia de la Calle, Azpilcueta Navarro); eighth, bank deposits being part of the monetary supply (Luis de Molina, Juan de Lugo); ninth, the impossibility of organizing society by coercive commands due to lack of information (Juan de Mariana); and lastly, the anarchocapitalist position that any unjustified intervention of the state violates natural law (Juan de Mariana) (ibid.). Let us go step by step through the evidence. Diego de Covarrubias y Leyva (1512-77) partly reached a correct understanding on the first key principle, subjective value theory. In 1555, he wrote: 
«the value of an article does not depend on its essential nature but on the subjective estimation of men, even if that estimation is foolish», illustrating his thesis with the example that «in the Indies wheat is dearer than in Spain because men esteem it more highly, though the nature of the wheat is the same in both places» (Huerta de Soto 2009b [1999], 206).

Most Spanish scholastics were not as subjectivist as Covarrubias, but they all agreed that labour or cost of production only play a minor role in determining the price (Grice-Hutchinson 1952, 49). A standard phrase of the scholastics was «common estimation» which referred to the aggregate of individual estimations setting the just price on the market. Thus the just price was eventually the market price. The scholastics hold to the common estimation due to moral reasons. In their view, consumers were poorer and more in need than producers. Thus they feared cost of production or labour could give producers an excuse to charge higher prices on poor people (ibid., 27). The second pronounced Spanish subjectivist was Luis Saravia de la Calle. In his Instrucción de mercaderes (Instruction of merchants, 1544), he denies that cost of production play any role in price determination:

Those who measure the just price by the labour, the costs, and risk incurred by the person who deals in the merchandise or produces it, or by the cost of transport or the expense of travelling to and from the fair, or by what he has to pay the factors for their industry, risk, and labour, are greatly in error, and still more so are those who allow a certain profit of a fifth or a tenth. For the just price arises from the abundance or scarcity of goods, merchants, and money, as has been said, and not from costs, labour, and risk. If we had to consider labour and risk in order to assess the just price, no merchant would ever suffer loss, nor would abundance or scarcity of goods and money enter into the question. Prices are not commonly fixed on the basis of costs. Why should a bale of linen brought overland from Brittany at great expense be worth more than one which is transported cheaply by sea? (...) Why should a book written out by hand be worth more than one which is printed, when the latter is better though it costs less to produce? The just price is found not by counting the cost but by the common estimation (Grice-Hutchinson 1952, 81-2). 
The Spanish scholastics also advanced the medieval view on the value of money. Their predecessors had argued that money derives its value either from 1) the fulfilment of its functions, e.g. as measure of value or means for exchange, 2) the decree of a prince or 3) the market estimation of the metal content (ibid., 30). The Spanish scholastics still stuck to these reasons as the determinants of the exchange value, but also applied their subjective theory on money. Therefore the estimation with which money is held, which depends on the usual factors like scarcity, supply, demand, utility etc., determines its value (ibid., 51). "Our writers thus brought goods and money within the scope of a single theory of value» (Grice-Hutchinson 1952, 50). Going away from their value theory, which will later be crucial for our research, we proceed to the second key principle: the correct relationship between prices and costs. It is again Saravia de la Calle in his Instrucción de mercaderes (1544) who realizes that prices determine costs and not vice versa:

Those who gauge the just price of an article by the labor, costs, and risks borne by the person who deals in or produces the merchandise are seriously mistaken; for the just price springs from the abundance or lack of goods, merchants, and money, and not from costs, labor, or risks (Huerta de Soto 2008 [2000], 30).

The dynamic nature of the market and the impossibility of the equilibrium model were recognized by the Jesuit cardinals Juan de Lugo and Juan de Salas. The market handles so much information that knowing equilibrium prices and other data becomes impossible for the central planner. Juan de Lugo expressed this insight already in 1643, when he wrote that equilibrium depended on so many circumstances that only God can know it (ibid., 31). Fourth, Castillo de Bovadilla and Luis de Molina described competition as a dynamic process of rivalry among sellers. Bovadilla wrote in his book Politica para corregidores (Politics for chief magistrates, 1585) that competition has the positive effect of the emulation of competitors. Additionally, he identified the following economic principle: «prices of products will decrease as a result of the abundance, mutual emulation and concurrence of sellers» (Huerta de Soto 2008 [2000], 31). 
The Spanish scholastics also rediscovered the law of time preference stating that, other things being equal, an actor always prefers present to future goods. Gilles de Lessines already discovered this law in 1285, but Martín de Azpilcueta formulated it anew as follows: «a claim on something is worth less than the thing itself, and ... it is plain that that which is not usable for a year is less valuable than something of the same quality which is usable at once» (Rothbard 2006a [1995], 107). Juan de Mariana, Covarrubias and Azpilcueta furthermore perceived the distorting influence of inflation, understood as artificial expansion of the money supply. Juan de Mariana expressed this insight most clearly in his book De Monetae Mutatione (On the Alteration of Money, 1609). There, he accused King Philipp II of debasing the copper coinage causing a price inflation in Spain. Instead of artificially expanding the money supply, the value of money must be estimated voluntarily:

Only a fool would try to separate these values in such a way that the legal price should differ from the natural. Foolish, nay, wicked the ruler who orders that a thing the common people value, let us say, at five should be sold for ten. Men are guided in this matter by common estimation founded on considerations of the quality of things, and of their abundance or scarcity. It would be vain for a Prince to seek to undermine these principles of commerce. 'Tis best to leave them intact instead of assailing them by force to the public detriment (Rothbard 2006a [1995], 120).

The Spanish scholastics also criticized fractional reserve banking. Saravia de la Calle viewed the violation of the deposit contract by bankers as illegitimate and a grave sin (Huerta de Soto 2008 [2000], 32). Tómas de Mercado, Azpilcueta and de la Calle demand that banks operate with a 100-percent reserve requirement. Even more, the Spaniards knew that deposits are part of the money supply. Luis de Molina realized in 1597 that banks increase the money supply by creating deposits out of thin air (ibid., 33). Lastly, Juan de Mariana anticipated two other Austrian key principles. He wrote that organizing society by coercive commands is impossible, because the authorities «do not know the people, nor the events, at least in terms of all their circumstances, upon which success depends. Inevitably they will commit many serious errors» (ibid., 33). 
He additionally anticipated anarchocapitalist theory in stating that any unjustified intervention by the state violates natural law (ibid., 34). Thus, given these ten anticipations, do researchers also believe that the Spanish scholastics transmitted their knowledge to later generations of economists?

\section{III \\ THE AUSTRIAN SCHOOL: OF SPANISH AND CATHOLIC ORIGIN?}

Rafael Termes writes in his introduction to Chafuen's book about Spanish late scholasticism: «I think, therefore, that we can conclude, whether Max Weber likes it or not, that the origins of economic liberalism or capitalism are Spanish and Catholic» (Chafuen 1991 [1986], 14; own translation). In what follows, it is examined whether more researchers agree with Termes' conclusion.

\section{Jesús Huerta de Soto}

One of the researchers who shares Termes' opinion is Huerta de Soto. He argues that the ideas of the school of Salamanca were «taken up» and given «a definite boost» by Menger (Huerta de Soto 2008 [2000], 34). Additionally, he identifies Spanish scholasticism as «the true origin of the Austrian school» (Huerta de Soto 2010 [2009]) and the University of Salamanca as «the birthplace of the Austrian school» (Huerta de Soto 2009a [1997], 265-6). Thus it is safe to say that Huerta de Soto defends the thesis that the Spanish scholastics influenced Carl Menger. Besides the evidence which we already saw before, Huerta de Soto backs his view with two other arguments. On the one hand, he mentions that Menger quotes Covarrubias in his Principles (Huerta de Soto 2008 [2000], 30). We examine this quote in the next section. He also argues that «intimate historical, political and cultural relations» existed between Austria and Spain:

To understand the influence that the Spanish scholastics exerted on the subsequent development of the Austrian School of economics, we must especially remember that in the sixteenth century the 
Emperor and King of Spain, Charles V, sent his brother, Ferdinand I, to be king of Austria. «Austria» means «eastern part of the Empire», an empire which at that time encompassed practically all of continental Europe, with the only notable exception of France, which remained isolated and surrounded by Spanish forces. Therefore it is easy to understand the Spanish Scholastics came to intellectually influence the Austrian school, a situation which was not a mere coincidence or caprice of history, but which arose from the intimate historical, political and cultural relations which developed between Spain and Austria beginning in the sixteenth century (Bérenguer 1993, 133-335). These relations would be maintained for several centuries, and Italy also played a vital role, as a cultural bridge across which the intellectual exchange between the far points of the empire (Spain and Austria) flowed (Huerta de Soto 2008 [2000], 34).

Two comments are important concerning this passage. First, Huerta de Soto only gives contextual evidence for a link. The «historical, political and cultural relations» between Austria and Spain might indicate a connection, but we cannot deduce out of it that the Spanish scholastics influenced Menger. We need more evidence to support this thesis. And second, Huerta de Soto identifies Italy as a «cultural bridge» across which the knowledge of the Spanish scholastics flowed. This statement can be interpreted in two ways. Either Huerta de Soto implies that the Spanish scholastics influenced the Italian economists, which then directly influenced Menger. Or he argues that the Italians influenced some unknown fourth party, which then influenced Menger. Both interpretations are investigated in later sections in which the fourth (and fifth) party are French (and German) economists.

\section{Marjorie Grice-Hutchinson}

The most significant research on the economic theory of the Spanish late scholastics was done by the British historian Marjorie Grice-Hutchinson. In her book The School of Salamanca, GriceHutchinson $(1952,60)$ identifies three spheres of knowledge in which the Spaniards made important contributions: the quantity theory of money, the purchasing-power parity theory and subjective value theory. Contributions in the first two spheres did not 
have a long-lasting influence. Jean Bodin for instance discovered independently the quantity theory, twelve years after Martín de Azpilcueta (ibid., 61). Grice-Hutchinson concludes: «It was, then, in their analysis of value that our Spanish writers appear to have made their most enduring contribution to economic theory» (ibid., 77). How does she trace back this contribution in The School of Salamanca? She begins by remarking that Jean-Baptiste Say was the «leading exponent» (ibid., 62-3) of the subjective value theory in the 19th century. This subjectivist view «may be traced back a step further to the writings of Condillac, Turgot, and Galiani» (ibid., 63) in the 18th century. With Galiani, who was at that time -in her view - the first in formulating a consistent subjective value theory, she stops in tracing the link:

Condillac and Turgot, like Jevons a century later, seem to have regarded their own emphasis on utility as a novelty. The only predecessor they acknowledge is Galiani, whose brilliant analysis of utility seems at first sight to have sprung fully mature into life: at any rate, Galiani himself gives us no clue to any earlier source (Grice-Hutchinson 1952, 63-4).

What she had of course not discovered was Galiani's reference to Covarrubias in Della Moneta (On money, 1751), in a chapter on value theory. Raymond de Roover $(1974,334)$ later discovered this citation. Table 1 displays all references to the Spanish scholastics which Grice-Hutchinson detected in the subsequent literature. By far the most references can be found in the Italian and Spanish literature of the 17th and 18th century. The Belgian Leonard Lessius was the most significant follower. He was so influenced by the Spanish scholastics that many thought of him as being a member of the school of Salamanca (Grice-Hutchinson 1998, 245). The only work which is cited in the Principles is Galiani's Della Moneta. We take a closer look at it in section six. Note that Grice-Hutchinson did not discover a reference to French economists like Turgot, Condillac, Quesnay or Say who also formulated quite subjective value theories. If anything, the scholastic doctrine could have flowed from Italy to Turgot and Condillac. Murray Rothbard argues for this connection in his essay New Light on the Prehistory of the Austrian School (1976). At the end, Grice-Hutchinson concludes: 
The Predominantly subjective or utility theory of value held by the Doctors was thus preserved and transmitted through many channels. It is not too much to say that from the rediscovery of Aristotle until modern times utility-theory has developed continuously, even the prestige of the English classical economists, and of Marx, being insufficient to submerge it completely. From the middle of the sixteenth century to the end of the seventeenth, the Spanish late scholastics played a leading part in this work of transmission and development (Grice-Hutchinson 1978, 115).

It seems that Grice-Hutchinson defends a link from Aristotle to all «modern» economists. Thereby the school of Salamanca played «a leading part» in transmitting the subjective doctrine of the Doctors. She does however not explicitly speak of a link between the Austrian school and the Spanish scholastics.

\section{TABLE 1}

REFERENCES TO THE SPANISH SCHOLASTICS, ACCORDING TO GRICE-HUTCHINSON (1978, 107-21; 1998)

\begin{tabular}{|c|c|}
\hline Country & Author(s) citing Spanish scholastics on economics ${ }^{1}$ \\
\hline Belgium & Leonard Lessius (De justitia et jure, 1605) \\
\hline Germany & $\begin{array}{c}\text { Samuel von Pufendorf (Elementorum jurisprudentiae } \\
\text { universalis libri 2, 1660; De jure naturae et gentium, 1672; De } \\
\text { officio hominis et civis juxta legem naturalem, 1673) }\end{array}$ \\
\hline Italy & $\begin{array}{c}\text { Pietro Catalano (Universi juris theologico-moralis corpus, } \\
\text { 1728), Martino Bonacina (Opera omnia, 1646), Antonio Diana } \\
\text { (Summa diana, 1646), Giambattista de Luca (Theatrum } \\
\text { veritatis et justitiae, 1669-81; Il dottor volgare, 1673), Clemente } \\
\text { Piselli (Theologiae moralis summa, 1710), Ferdinando Galiani } \\
\text { (Della Moneta*, 1750) }\end{array}$ \\
\hline Spain & $\begin{array}{c}\text { Pedro Rodríguez de Campomanes (Respuesta fiscal sobre } \\
\text { abolir la tasa y establecer el comercio de granos, 1764), } \\
\text { Manuel de Zubiaur (Opúsculo de teología moral, 1716), Pedro } \\
\text { de Calatayud (Doctrinas prácticas, 1739), Jose María Uría de } \\
\text { Nafarrondo (Aumento del comercio con seguridad de } \\
\text { conciencia, 1785) }\end{array}$ \\
\hline
\end{tabular}

Notes: ${ }^{1}$ Text and numbers in brackets indicate title and publishing year of the publication.

*indicates that Menger cites this publication in his Principles. 


\section{Murray Rothbard}

His contribution is to synthesize the research of Grice-Hutchinson, Raymond de Roover and Emil Kauder. He emphasizes the high level of economic knowledge in scholastic thought which culminated in the writings of the Salamancian scholastics. Rothbard (2006c [1976]) writes for instance about their contributions to value theory: «But it was the sixteenth-century Spanish Scholastics who developed the purely subjective and pro-free-market theory of value.» Rothbard takes a more moderate standpoint on Spanish scholasticism compared to Huerta de Soto. He identifies a link between all scholastics and the Austrian school and does not attach so much importance to Spanish scholasticism:

In recent decades, the revisionist scholars have clearly altered our knowledge of the prehistory of the Austrian school of economics. We see emerging a long and mighty tradition of proto-Austrian Scholastic economics, founded on Aristotle, continuing through the Middle Ages and the later Italian and Spanish Scholastics, and then influencing the French and Italian economists before and up till the day of Adam Smith. The achievement of Carl Menger and the Austrians was not so much to found a totally new system on the framework of British classical political economy as to revive and elaborate upon the older tradition that had been shunted aside by the classical school (Rothbard 2006c [1976]).

As is so often, there is a problem with the ambiguous terminology used on the issue. What is meant by the term «revive and elaborate upon»? Rothbard does not go into further detail on this point. Although the above passage suggests that he believes in a scholastic influence on Menger, he only traces this influence to Say and does not continue to Menger (compare Figure 1). In general, there exists an English and a continental tradition in Rothbard's (and Grice-Hutchinson's) view. The English tradition got it wrong. Although it was influenced by scholastic thought, it turned to a labour theory of value and paved the way for Karl Marx. The Dutchmen Grotius and Lessius were first influenced by the Spaniards, the later frequently cites them in his works. Grotius' teachings were taken up by the German Lutheran jurist Samuel Pufendorf. 
Unfortunately, Pufendorf dropped many citations to the Spanish scholastics (Rothbard 2006c [1976]). Thus when Carmichael translated Pufendorf's writings into English, knowledge of the scholastic traces was lost. Hutcheson, a student of Carmichael, and his student Adam Smith, finally dropped out scholastic influences on value theory. The economists on the continent preserved this scholastic tradition which ranges back to Aritotle. The Italians Lottini, Genovesi and especially Galiani, who cites Covarrubias on value theory, were influenced by the Spaniards. «From Galiani the central role of utility, scarcity, and the common estimation of the market spread to France» (Rothbard 2006c [1976]) —namely to Condillac, Turgot and Quesnay. Condillac and Turgot then influenced Say. In brief, there is no hard evidence in the literature for a link between the (Spanish) scholastics and Menger- with the possible exception of the quote of Covarrubias, to which we now turn our attention.

FIGURE 1

ROTHBARD'S (2006C [1976]) SYNTHESIZATION OF ROOVER, KAUDER AND GRICE-HUTCHINSON

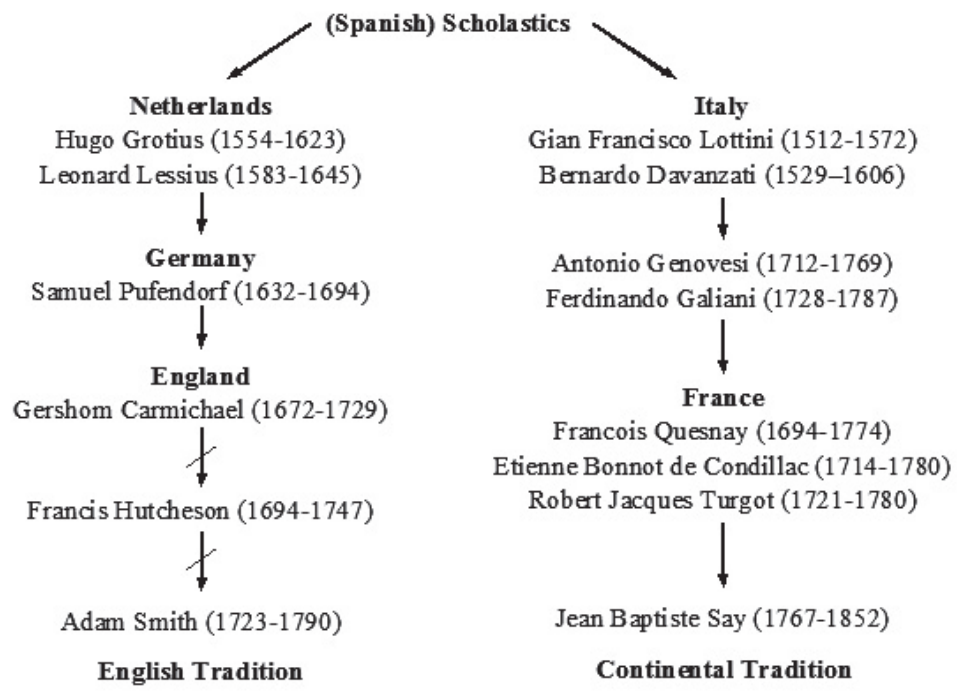


IV

\section{THE «MISSING LINK» TO MENGER}

In their history The Austrian School of Economics, Schulak/Unterköfler criticize Huerta de Soto for not providing sufficient evidence for the thesis that the Spanish scholastics influenced Menger. In their words: «Huerta de Soto has also become well known for his theory that Spanish late scholasticism should be considered the forerunner of the Austrian School; he has yet to provide the crucial "missing link" between the scholastic tradition and Menger» (Schulak/Unterköfler 2011 [2009], 176). Is there really no direct link between Menger and Spanish scholasticism except for the quote of Covarrubias in the Principles? There are two major sources for research on Menger: his economic writings and his library. Let us see if we can find there a reference or a book relating to the Spanish scholastics.

\section{References in Menger's Writings}

There is one reference in his works. Menger cites Covarrubias in the eighth chapter «The Theory of Money» of his Principles:

These tracts [ iThe extremely fertile literature of the middle ages and the sixteenth century»] were chiefly concerned with the practical problems of coinage, especially with the question of the existence and the limits of the right of princes to change the metallic content of coins, and with the consequences of these changes on public wealth. This problem had become important because of frequent abuses of the coinage by government. In this context, several authors also take the opportunity of discussing the problem of the origin of money, which they solve on the basis of the findings of the writers of antiquity, with regular reference to Aristotle. See (...) Didacus Covarruvias, Veterum numismatum collatio, in ibid., p. 648; (...). ${ }^{1}$ Summarizing the course followed by the investigations of

1 Veterum numismatum collatio is a study on the maravedi's decrease in purchasing power during the 15th century in Spain which contains many price statistics (Huerta de Soto 2008 [2000], 30). 
these writers, they almost always begin by showing the difficulties to trade arising from pure barter. They next show how it is possible to remove these difficulties by the introduction of money. In the further course of their arguments, they stress the special suitability of the precious metals for serving as money, and finally, citing Aristotle, they reach the conclusion that the precious metals actually became money by the legislation of men. (...) However meritorious the service of many of these writers in opposing abuses of the coinage on the part of princes, they did not therefore improve upon the views of antiquity so far as the question of the origin of money is concerned (Menger 2007 [1871], 316-7; emphasis in original).

Menger cites Covarrubias disapprovingly and concludes that he, as well as six other authors of the period, did not improve upon the theory of the origin of money. Aristotle argued that money comes into existence by law or convention, and does not spontaneously evolve in society. Menger is not in accordance with this standpoint of the Greek philosopher and Covarrubias. Furthermore, he cites Covarrubias not on subjective value but on the origin of money. If Menger would have considered Covarrubias' contributions on subjective value as significant, why does he not quote him on that? This is particularly odd given the fact that Menger belonged to an intellectual milieu in which correct and extensive citation played an essential role. It seems unlikely that he would not mention a 16th-century economist who «expressed better than anyone before him the essence of the subjective theory of value» (Huerta de Soto 2008 [2000], 29). Especially since Wilhelm Roscher — the German expert on the history of economic ideas- praised Menger's Principles for its «thorough knowledge of the history of economic thought» (Roscher 1874, 1040). Seen in this context, the quote of Covarrubias becomes rather evidence against a link between Salamanca and Vienna. ${ }^{2}$

\footnotetext{
${ }^{2}$ If Menger was unaware of Covarrubias' works which contain his subjective value theory, it would point to what Hülsmann $(2007,111-2)$ writes in his Mises-biography The Last Knight of Liberalism: «In developing his theory of value and prices, Menger relied on the remnants of an ancient price theory from the late-Scholastic School of Salamanca, which in the sixteenth and early seventeenth centuries had stressed precisely those subjective features of the pricing process that were conspicuously absent
} 
Böhm-Bawerk also cites Covarrubias in the first chapter of his Capital and Interest, in which he talks about «The opposition to interest.» There, Böhm-Bawerk elaborates on arguments which were put forward against interest-taking. Böhm-Bawerk starts with the Aristotelian view of the bareness of money, i.e., money is not productive in itself and hence making money out of money is unnatural and unjust. In this context, he cites Covarrubias who formulated this argument anew:

And in still plainer terms Covarruvias: 'The fourth ground is that money brings forth no fruit from itself, nor gives birth to anything. On this account it is inadmissible and unfair to take anything over and above the lent sum for the use of the same, since this is not so much taken for money, which brings forth no fruit as from the industry from another' (Böhm-Bawerk [1884] 1890, 22).

It is clear that Böhm-Bawerk disagrees with this opinion. Interest is taken because people value present goods higher than future goods. To outlaw interest is impossible. Hence we have a disapproving quote in the first book of Capital and Interest which is about the history of ideas on interest. As Menger, Böhm-Bawerk most likely quotes Covarrubias to show his knowledge in the history of economic thought. Böhm-Bawerk cites the Spaniard a second time on the usury question. Covarrubias now puts the following antiinterest argument of Thomas Aquinas forward: there are things whose use consists in consuming them, e.g. articles like wine or bread. Hence use of these articles cannot be separated from their consumption and if the use of the article is sold, the article itself must be transferred too. In other words, it is prohibited to sell bread and its use separately. The same applies to money in a credit contract: The debtor has to pay the borrowed sum back and money

from the British classical school. But the Spanish late-scholastics never produced a treatise on economics, and their discoveries about the nature of value and prices were scattered across thousands of pages.» Hülsmann seems to believe in a link when he writes that Menger «relied on the remnants» of a subjective value theory from the school of Salamanca. But he also emphasizes that the knowledge of the Spaniards was "scattered across thousands of pages». If this is true, it is easy to see why Menger (and Böhm-Bawerk) did not come across the subjective value theory in Covarrubias. 
for use of the same, which means he pays two times for one thing (Böhm-Bawerk 1890 [1884], 22). Covarrubias formulated this argument as follows:

To take any profit for the use of the object itself, and eventually the object itself, is unjust and the exchange is fraudulent, because that which does not belong to the price is sold ... since either the creditor receives that profit for his part, therefore receiving its valuation twice, or he receives an unjust value of the part. If for the use of an object, they cannot be estimated separate from the part, and thus the same part is sold twice (ibid.; own translation).

Again, Böhm-Bawerk does not agree with this argument against usury. Both quotes are from Variorum Resolutionum, which is not the work Menger quotes in his Principles. In total, we found three disapproving quotes of Covarrubias: one in Menger, two in BöhmBawerk. None are about subjective value theory.

\section{The Carl Menger Collection ${ }^{3}$}

Being a professor at the university of Vienna, Menger was probably one of the best-paid men in the Austro-Hungarian Empire. Streissler (1990a, 62-3) estimates Menger's salary at $\$ 500,000$ in relative income terms at a purchasing power of 1990 - and Menger did not have to pay many taxes. As Streissler remarks, «[p]rofessional chairs thus were not only among the very highly honored but also among the best-paid positions in the German-speaking world» (ibid., 63). This enormous salary explains why Menger could accumulate a library with more than 25,000 volumes (Schulak/Unterköfler 2011 [2009], 32). Many first editions of the classical

\footnotetext{
${ }^{3}$ We researched in the Carl Menger Collection for the following Spanish scholastics: Diego de Covarrubias y Leyva, Luis Saravia de la Calle, Juan de Lugo, Juan de Salas, Castillo de Bovadilla, Luis de Molina, Martín de Azpilcueta, Juan de Mariana. These are the names mentioned by Professor Huerta de Soto (2008 [2000], 29-37). We additionally looked for all scholastics mentioned by Murray Rothbard (2006a [1995], 99-133): Francisco de Vitoria, Domingo de Soto, Juan de Medina, Tomás de Mercado, Francisco Garcia, Domingo Báñez, Francisco Suarez.
} 
economists are part of this library, and numerous comments in the books show us Menger's intellectual evolution. After Menger's death in 1921, his widow Hermine Andermann (1864-1924) sold approximately 19,100 volumes to the Hitotsubashi University in Tokyo, Japan.

The Spanish scholastics appear two times in the Carl Menger Collection at the Hitotsubashi University. There is one work by Luis de Molina with the title Ludovici Molinae nouissimis commentarijs, E interpretationibus ad bullam Pij Quinti de censibus. The title suggests that this work is not about economics. It appears in a book which is titled Tractatus de censibus. The book also contains texts by Ludovicus Cenci and Giovanni Battista Leonelli. It was published in Venice in 1629 and consists of three volumes (Hitotsubashi University 2016a). Covarrubias appears in a book with the title Tractatvs varii atque vtiles de monetis. This book is about economics. Covarrubias contributed as one of eleven authors with Sequuntur Duo capita ad rem monetariam pertinentia desumpta ex libro practicarum quæstionum D. Didaci Couuarruuias à Leyna (Two Paragraphs follow with respect to the coinage taken from the book of practical investigations of Diego Covarrubias y Leyva). Neither Menger nor Böhm-Bawerk seem to cite this text. The book was published in Cologne in 1574 and consists of eight volumes (Hitotsubashi University 2016b).

The result: two books by the Spanish scholastics which are not monographs, but text collections written together with two or ten other scholastics. This is not much. These two books account for approximately 0.01 percent of the Carl Menger Collection. ${ }^{4}$ Compare them with the following numbers: there are 2 books by Oresme, 3 by Gabriel Biel, 5 by Grotius, 7 by Dante, 7 by August Comte, 21 by Wieser, 21 by Schmoller, 29 by Adam Smith, 33 by Böhm-Bawerk and 37 by Karl Marx. Interestingly, Menger possessed a lot of different editions and translations of the Wealth of Nations. ${ }^{5}$ The missing

\footnotetext{
${ }^{4}$ There are 16,108 books or other writings in the Carl Menger Collection. Some books consist of various volumes so that the total number of volumes is approximately 19,100 .

${ }^{5}$ Menger owned eleven English editions of the Wealth of Nations published in 1776, 1778, 1784, 1786, 1789, 1799, 1811, 1817, 1828, 1893 and 1896. These editions include the first five editions which appeared in English. Menger also possessed six
} 
link is also illustrated by the fact that only 17 books are written in Spanish and 14 are translated from Spanish into another language. These 31 Spanish books account for 0.19 percent of the collection. Spanish even comes after Hungarian (42 books) and Russian (38 books) at rank \#9. Most books are in German (54 percent), followed by French (19 percent), English (17 percent) and Latin (4 percent). Thus Spanish late scholasticism or Spanish literature are almost non-existent in the collection. Menger knew some works of the Spanish scholastics but did probably not consider them to be important. ${ }^{6}$ Let us see if there is evidence for an indirect influence via a transmitter like German economics.

\section{$\mathrm{V}$ \\ MENGER AND GERMAN ECONOMICS}

«As if out of another world - unexplainable and uncausedMenger, Böhm-Bawerk and Wieser surfaced in the social economics of that day» (Streissler 1990a, 31). These are the words of Joseph Schumpeter in an article of 1914. He is one of the main originators of what Erich Streissler (ibid.) calls a «myth»: that the Austrian school developed their ideas independently of German economics. «It is easy to show that very few of the basic ideas of Menger's Principles cannot be found foreshadowed in the books of German economics» (ibid.). In the following, we show how German economists anticipated and influenced Menger. After that, we examine whether they were influenced by the Spanish scholastics.

German editions of 1776-8, 1796-9, 1799, 1810, 1846-7 and 1861 as well as three French editions of 1788, 1794 and 1800-1. These are in total 20 editions which consist of 69 volumes. These are far more editions than of Say's Traité and Cours (each 7 times), Ricardo's Principles (5), Rau's Grundsätze (3) or Condillac's Le commerce (2). Even the most-quoted book in Menger's Principles, the first volume of Roscher's System, just appears 12 times. At least in the case of Roscher's textbook, Menger had the chance to obtain more editions. The 25th German edition appeared in 1918-three years before Menger's death-and there were also English and French translations.

${ }^{6}$ Still, there could be something in the Carl Menger Papers at the Duke University. 


\section{The German Origin of Menger's Thought}

In the 1910s, Schumpeter did not have many positive things to say about the older German economists. He remarked in an article of 1914: «On these little has to be said. Not as if they had written little; not as if not now and then something of value cannot be found in them. But no spirit flows in these books» (Streissler 1990a, 41). Wieser even stated that concepts like wants, goods, value in use or value in exchange were «empty boxes» (ibid., 40) in the German textbook literature. These views are usually based on a misconception of German history and especially its history of economic thought. As Streissler (ibid., 31-2) explains in his outstanding article, Schmoller and the younger historical school came into prominence after the rise of a Prussian-dominated central state in 1871 . Before, Germany had politically been much more fragmented and was intellectually dominated by universities of smaller, independent states. Examples are Heidelberg or Freiburg in Baden, Munich in Bavaria, Tübingen in Württemberg and Leipzig in Saxony. It is in these universities where the leading exponents of the older historical school taught —like Hufeland (1760-1815), Rau (1792-1870), Hermann (1795-1868) or Roscher (1817-94). ${ }^{7}$ Hermann, a professor at the Ludwig Maximilian University of Munich, realized for instance that prices determine cost:

Even if we were willing to leave aside completely the large number of price determinations where we can think of no connection whatsoever with production costs, we would still find that even for those goods which come to the market regularly and in any desired quantity the price is in no way determined by cost alone, as Ricardo and his school teach. The first and most important factor determining price is, in fact, in all cases demand, the main roots of which are the value in use and the ability to pay of the

\footnotetext{
${ }^{7}$ Winkel $(1977,101-4)$ makes the distinction between a younger and older historical school. Streissler $(1990 \mathrm{a}, 32)$ similarly distinguishes between the «Schmoller school» and the «older men», naming Hermann, Rau and Roscher. Even Mises, who rather wished to see no connection between the Austrians and German economics (Streissler 1990a, 40-1; Gabriel 2012, 38), names Roscher, Hildebrand and Knies as «the champions of the older [historical] school» (Mises 1990 [1962], 43).
} 
purchasers. From demand and from what demanders are willing to bid for a good we see which amount of goods they are willing to forgo for the sake of the desired good and this determines how high the cost of the least remunerative production can be (Hermann 1832, 95).

He wrote this text as early as in 1832 in his magnum opus Staatswirthschaftliche Untersuchungen (State-economic investigations), in a section titled «The influence of price changes on costs». The last sentence, which states that demand indicates the amount of goods consumers are willing to forgo for the desired good which in turn determines costs of the least remunerative production, strongly resembles Wieser's opportunity cost-argument. As Streissler $(1990 a, 42)$ explains, this argument was widely used in the German literature after Hermann and was even employed before 1832. German economists also emphasized the role of the entrepreneur. Karl Heinrich Rau (1792-1870) — professor in Heidelberg and teacher of the young Frederick I, Grand Duke of Baden - treated the entrepreneur as a fourth factor of production. This is a very similar emphasis on entrepreneurship like in the Austrian theory. According to Rau, entrepreneurship consists «in the combination of factors, in drawing a plan for their most advantageous use, and in the supervision of the execution of this plan by his assistants» (ibid., 52). Additionally, the entrepreneur should be compensated for «the danger of total loss or at least loss of some of the costs» which especially arises due to «the greater or lesser difficulty in forecasting the level of future prices» (ibid., 52).

It is safe to say that Karl Heinrich Rau surpassed the neoclassical concept of the entrepreneur as a combiner of production factors and hinted at uncertainty of the future as an important part of entrepreneurship. ${ }^{8}$ Gottlieb Hufeland similarly argued that the entrepreneur receives an income which differs from the income in land, labour or capital. This Hufeland, who was a professor of law and mayor of Danzig, was also the German authority on subjectivism and subjective value. He writes that «all goods are only goods

\footnotetext{
${ }^{8}$ On 19th century German economics and its theory of entrepreneurship, see Streissler (1989).
} 
by virtue of the mind-picture which one man or several men make themselves of them» (Hufeland 1815 [1807], 17) and that there is «absolute sovereignty of opinion in the realm of goods and of wealth» (ibid., 19) and hence «things that become goods (...) though they are mainly made by labour do not become goods because of that labour» (ibid., 32). Hufeland did not write these sentences in 1850, but as early as in 1807 in his Neue Grundlegung der Staatswirthschaftskunst. Unsurprisingly, Streissler identifies him as «the constantly quoted first author on subjective economic concepts in German economics» (Streissler 1990a, 42).

This subjectivist outlook was deeply ingrained in the German literature. Albert Schäffle explains value in 1867 as follows: «Value [is] a relationship between all goods in human consciousness (...) [it is] predominantly of a subjective nature» (Schäffle 1867, 52; emphasis in original). Schäffle was Menger's predecessor at the university of Vienna and was likely to be the referee for his habilitation, but became minister of trade in 1871 (Streissler 1990a, 34). Wilhelm Roscher, to whom Menger dedicated his Principles, identifies a good as «anything which is known to be useful for the satisfaction of a true human need» (Roscher 1843, 2). Hermann defines want as «the sense of deficiency with the endeavour to address it» (Hermann 1874, 5). Building on these subjectivist insights, Karl Knies (1821-98) realized in 1855 that exchange is only possible with inverse valuations:

Exchange presupposes that for the individuals concerned value in use of the same quantity of goods is of different magnitude. Exchange takes place not because two quantities of two goods are equal, but because they are on both sides in opposite ways esteemed unequal (Knies 1855, 467).

This idea was not new. According to Streissler (1990a, 44), Rau had already presented it before. Knies was a professor at the Heidelberg university where Wieser and Böhm-Bawerk, while still being students, presented marginalist papers in his seminar (Streissler 1990a, 34-5). So deep-seated was the subjectivist doctrine in German economics that Roscher, in referring to Condillac, called the labour theory of value an «English view» (Roscher 1864 [1854], 
200). Karl Marx attacked Roscher thereupon with the following words: "It is because Condillac has not the remotest idea of the nature of exchange value that he has been chosen by Herr Professor Wilhelm Roscher as a proper person to answer for the soundness of his own childish notions» (Marx 1909 [1867], 177-8). The German economists also discovered many marginal concepts. Bruno Hildebrand (1812-78) was in 1848 the first to formulate the law of diminishing marginal utility: «The more the quantity of a useful commodity is increased, the more the utility of each price diminishes as long as the want has not changed» (Hildebrand 1848, 318). Menger was aware of this quote because he cites and criticizes the succeeding sentences of Hildebrand's book in his Principles, and speaks of them as "an incomparable impetus to investigation» (Menger 2007 [1871], 297). Decreasing marginal utility can also be found in Mangoldt $(1863,48)$ and Roscher $(1864$ [1854], 10). The German economists also recognized that actors tend to equalize the marginal utilities of goods they possess. Peter Mischler (1821-64), Menger's professor of economics in Prague, expresses this insight as follows:

Everyone will buy no more of a certain type of a good for a given want than he can use from a rational point of view (...) if he has a surplus (...) he will try to use it as a means of exchange for acquiring another good (Mischler 1857, 231).

There were even more sophisticated marginal concepts present in German economics. Karl Wolfgang Schüz (1811-75) hints at factor pricing by the marginal value product:

The price of a service is determined according to the general rule of price formation. Therefore we have first to look at the value of labour. But the value of labour is esteemed by him who pays wages according to its result. The more this result answers to his demands and wants, the more valuable the labour is to him and the more is paid for it in the utmost case (maximum price). In any business the wage is thus determined (1) by the degree of productivity of labour and the remunerativeness of the occupation which is carried on with the cooperation of the labourer (Schüz 1843, 286). 
Hermann $(1832,281)$ hints at marginal factor pricing too, as well as Roscher (1897 [1854], 481) who says: «In each producing establishment (and also in the economy as a whole!) the additional product which the worker, who is last employed, produces is of decisive importance for the level of wages of his equals.» The German economists also anticipated the Austrian business cycle theory in parts. Schäffle $(1867,214-9)$ inter alia ascribes crisis to variations in interest rates and lack of information by generations which never experienced a crisis. Streissler (1990a, 61-2) even states about a chapter of Lorenz von Stein's textbook: «There the astonished reader is already presented with the so-called Austrian Theory of the Business Cycle, the expansion and contraction of credit, at considerable length (227-28)!» Actually, Lorenz von Stein does not identify a market interest rate below its natural level as the cause of the business cycle. He nevertheless comes to a very Austrian conclusion:

Therefore the cause of the trade crisis lies in the reasons which stop the sales revenues. Since the sales revenues are affected by the sales, a lack of sales becomes the first reason of the crisis. The cause of this lack, however, is due to the fact that production suddenly increases more rapidly than consumption, whereby a part of the products becomes unsaleable. The cause of the sudden increase of production lies in the sudden growth of the capital of firms; and since that is generated by credit, the sudden increase of credit is, apart from the interest rate, the cause of the trade crisis. The credit therefore becomes, just as much as it is a source of progress, also the source of danger (Stein 1858, 228).

This is a remarkable statement more than 50 years before Mises first formulated the Austrian business cycle theory. Stein clearly perceives the dangers of credit expansion. He characterizes the crisis as an overinvestment crisis during which "production suddenly increases more rapidly than consumption». This is caused by higher investment of firms which is "generated by credit». Therefore credit and the interest rate are the causes of the business cycle. Sixth, the German economists analyzed all prices in the same theoretical supply-demand-framework (Streissler 1990a, 47). In other words, they had a kind of proto-Austrian general price theory. Like 
Menger, many German economists presented isolated exchange as well as one- and two-sided competition in their textbooks. This is true for Roscher who praised Menger for his treatment of price theory (Roscher 1874, 1040). The German economists even foreshadowed Mises's argument that economic calculation is impossible under socialism. Hildebrand already wrote in 1848, under the title «All socialist organization plans are impracticable»:

Furthermore, as individual labor capabilities, talents, and wants are different everywhere, any law of distribution and accommodation presupposes the existence of an absolute measure of individual contributions to production and consumption. Yet, such a measure has neither been discovered, nor is it possible because these contributions are individual, that is, infinitely various, not only quantitatively but also qualitatively, and therefore not objectively measurable (Hildebrand 1848, 265).

Hildebrand argues that individual contributions to production are «not objectively measurable» in the absence of money prices, thus there is no law of distribution and accommodation for the socialist commonwealth. Schäffle even anticipated the calculation problem (Braun 2016, 134). He wrote in 1870:

The economic miracle generated by money and the money economy is based on the precise and homogeneous value calculation which can, for the entirety of all economic processes, only be performed with money. (...) The socially homogeneous valuation process would be impossible without money, and therefore also the highest degree of efficiency would be impossible, namely economy and good husbandry with respect to society as a whole (Schäffle 1870, 398).

Any society which would eliminate the use of money would lose «all stable yardsticks of value» and would remain without «any clue concerning the direction of the economy» (Schäffle 1870, 401). Mises was at least aware of Schäffle's works, because he cites two of them in the first edition of Socialism (Mises 1922, 124 \& 163). In short, the German economists articulated some of the key insights of the Austrian school, specifically: first, the correct relationship between prices and costs (Hermann); second, the emphasis on 
entrepreneurship (Rau, Hufeland); third, a thorough subjectivism with a subjective theory of value (Hufeland, Schäffle, Roscher, Knies); fourth, the law of diminishing marginal utility (Hildebrand, Mangoldt, Roscher) and other marginal insights (Hildebrand, Mischler, Schüz, Roscher); fifth, a proto-Austrian price theory (Roscher); sixth, a partial understanding of business cycles (Stein, Schäffle) and lastly, the impossibility of economic calculation under socialism (Hildebrand, Schäffle) ${ }^{9}$. Roscher seemed to be correct when he wrote more than 140 years ago: «German economics is at least the equal of any economics in foreign countries» (Roscher 1874, 1011). Thus the big question is of course: did the German economists also influence Menger? Who could better answer this question than Menger himself:

It was a special pleasure to me that the field here treated, comprising the most general principles of our science, is in no small degree so truly the product of recent development in German political economy, and that the reform of the most important principles of our science here attempted is therefore built upon a foundation laid by previous work that was produced almost entirely by the industry of German scholars. Let this work be regarded, therefore,

${ }^{9}$ We have to point out that it would go beyond the scope of this work to highlight all the German anticipations. Nevertheless, two important fields remain where the German economists foreshadowed or influenced Menger, namely monetary theory and economic liberalism. Gabriel $(2012,58)$ reasons that the older German economists, in particular Karl Knies, presented essential points of the Misesian monetary theory. Knies wrote the 1000-pages treatise Geld und Credit (1873-9, Money and Credit) which was praised by Mises as a «remarkable book on money and credit»(Mises 1990 [1962], 39). Gabriel $(2012,58)$ thinks that many German contributions on monetary theory flowed from Menger and Böhm-Bawerk to Mises. In respect to economic liberalism, Menger was -in the words of Streissler (1990b, 110) — «a classical liberal of the purest water». Some older German economists were also classical liberals and followers of Adam Smith. Schüller $(1899,43)$ identifies Kraus, Lotz, Jacob, Nebenius and Rau. The Grundsätze by Rau were also «[t]he main textbook» (Streissler 1994, 6) which Menger used in his lectures on economic policy to the crown prince Rudolf, whereas the framework and most arguments came from the Wealth of Nations (ibid.). Winkel (1977, 20; own translation) remarks in his history of 19th century German economics: «Generally, the doctrine of economic liberalism was so wide-spread in Germany during the first two decades of the 19th century that one can speak of it as the "ruling doctrine."» On economic liberalism, Menger and 19th century German economics, see Streissler (1997, 73-85). 
as a friendly greeting from a collaborator in Austria, and as a faint echo of the scientific suggestions so abundantly lavished on us Austrians by Germany through the many outstanding scholars she has sent us and through her excellent publications (Menger 2007 [1871], 49).

This is Carl Menger in the introduction of his Principles, naming himself a «collaborator» of German scholars and his Principles «a faint echo» of German scientific suggestions. Note that he believes the Principles to be based on «previous work that was produced almost entirely by the industry of German scholars.» These are by the way the only two times he mentions Austria(ns) in his book, except for a reference to the Austrian civil code and the Austrian currency (Streissler 1990a, 33). "Germany», the "Germans» or «German» contributions on the other hand are mentioned no less than 23 times (ibid.), including in passages like: «A deeper treatment of the problem of the measure of use value is to be found only among the German writers» (Menger 2007 [1871], 297). Or: «Perhaps nothing reveals the German tendency toward philosophical penetration of economics and the practical sense of the English better than a comparison of the treatments given the theory of value by German and English writers» (ibid., 307).

Furthermore, Menger mostly quotes German economists. Table 2 shows the ten most-quoted authors of his Principles. As can be seen, five are Germans and rank \#1 and \#2 are occupied by Germans. The French economists Say, Condillac and Turgot are also often cited. The Carl Menger Collection contains most books for Roscher, only Hermann and Aristotle have a one-digit number of books. Streissler $(1990 a, 35)$ reports that English authors are little quoted by Menger and that German authors like Rau or Roscher cite English and non-German authors more often. Streissler (1990a, 38) concludes: «Menger thus tried to attach himself closely to German economics, in contrast to English and even his native Austrian economics.» And the German economists received Menger very positively. Roscher devotes to him four lines of his history of economic thought, which came out in 1874 (only three years after Menger's Principles). He identifies Menger as one of «those economists who are continuing in the road of Hermann» (Roscher 1874, 
1039) and praises him for «his very abstract, always original and frequently quite fruitful analysis» (ibid., 1040). This was a high compliment and it was used as rationale for Menger's appointment as full professor. ${ }^{10}$ Wieser admitted too that Menger was influenced by German economics: «It is usually overlooked that M.'s Principles had been prepared for in an important way by the older [!] German theory» (Streissler 1990a, 40; emphasis in original). He even describes Menger as «sprouted from the soil of older German economics» (ibid.; own translation). Thus in sum, German economics seems to be the most significant influence on Menger. The Austrian school with its subjectivism and economic liberalism is —as Streissler (1997, 73; own translation) remarks— «a reuptake and continuation» of mid-19th century German economics. If the Spanish value doctrine was taken up by Menger, the influence must have flowed over Germany.

${ }^{10}$ The quote of Menger's personal file at the University of Vienna reads as: «Roscher himself, presently one of the first authorities in the sphere of economics, speaks of Menger in his Geschichte der Volkswirtschaftslehre in Deutschland [History of Economics in Germany] with special appreciation» (Streissler 1990a, 38; emphasis in original and own translation). 
TABLE 2

THE TEN MOST QUOTED AUTHORS IN THE PRINCIPLES, ACCORDING TO STREISSLER (1990A, 34-5)

\begin{tabular}{|c|c|c|c|}
\hline Rank & Author & Number of quotes & $\begin{array}{c}\text { Number } \\
\text { of books } \\
\text { in Carl Menger } \\
\text { Collection }\end{array}$ \\
\hline 1 & Roscher & 17 & 46 \\
\hline 2 & Hermann & 12 & 7 \\
\hline 3 & Adam Smith & 11 & 29 \\
\hline 4 & Schäffle & 10 & 27 \\
\hline & Jean-Baptiste & 10 & 25 \\
\hline 5 & Say & 9 & 11 \\
\hline 6 & Aristotle & 9 & 22 \\
\hline 7 & Condillac & 8 & 23 \\
\hline & Rau & 7 & 10 \\
\hline & Turgot & 7 & 4 \\
\hline
\end{tabular}

\section{A Link between Spain and Germany?}

To cut a long story short: there seems to be no influence. There are only three quotes of Juan de Mariana in Roscher's System der Volkswirthschaft (1854). All other German authors quoted at least two times in the Principles do not cite the Spanish scholastics. A critic might say now: «Only three quotes? This is so little that you must have overlooked something!» There is some merit to it. The German textbooks which were used for the key word research may not be appropriately digitalized. Another problem could be some unknown notations for the names of the Spanish scholastics. Menger $(1871,257)$ speaks for instance of «Couarouvia». However, we often looked not for the full names but for abbreviations like «Azpil» or «Cova». And many of the shorter articles were controlled with a visual inspection of the text and the footnotes. Additionally, we could find the quotes of Covarrubias which Roover $(1974,334)$ and Huerta de Soto $(2008$ [2000], 30) detect in the Italian 
literature (in Galiani and Davanzati). If this method works for the Italians, why should it not work for the Germans? It also makes perfect sense that it is Roscher who cites Mariana. Roscher was an expert in the history of ideas with an «unrivaled knowledge of the history of thought» (Streissler 1990a, 53). His monumental 1000-pages history of German thought is still relevant today. It seems plausible that such an eminent scholar would also know of and cite Spanish scholastic literature of the 16th century. Furthermore, Roscher again solely cites Mariana's De rege in his 1000-pages history and does not mention other Spanish scholastics. ${ }^{11}$ It is unlikely that Roscher would not mention a Spanish influence in this book if our Spanish writers influenced the German economists. Thus results may actually be accurate and there is not more; however, we should be cautious and refrain from interpreting too much into them.

Table 3 shows all German economists which Menger cites at least two times in his Principles. These are 26 books or journal articles by 16 German economists. Not included are all Germans which are cited less than two times. Thus Table 3 presents the who is who of German economics. Every important thinker like Rau, Knies, Roscher, Hermann or Hufeland is present. Thus we have a kind of representative sample of the German textbook literature. Our sample includes Rau's textbook Grundsätze der Volkswirthschaftslehre (1826). This book has the same title like Menger's Principles. It was one of the first to which Menger turned in preparing his habilitation, as shown by the following entry in his diary: «1867 Sept. Throw myself into political economy. Studied Rau, etc. Was partly free, partly at the Debatte, later the Tagespresse» (Yagi 2011, 33; emphasis in original). If there are little quotes in this sample, there is likely little in the rest of the German literature. Our numbers of citations are similar to Streissler's numbers. The main difference is Streissler's 9 instead of 11 (1) quotes for Schäffle, and 12 instead of 9 (2) for Hermann.

As said, the three quotes of Mariana's De rege et regis institutione (1599) can be found in Roscher's System der Volkswirthschaftslehre (1854). De rege contains a defence of tyrannicide and was burnt in

${ }^{11}$ Roscher's history was controlled by a visual inspection of the author index. 
France after Henry IV was assassinated (Rothbard 2006 [1995], 1179). The System was the major economic textbook in Germany during the second half of the 19th century. Its six volumes came out in 26 editions until 1922, being among others translated into English and French (Streissler 1990a, 52-3). The book was so influential that Knies bitterly noted citation by Roscher could make or impair a German-language economist (Knies 1883, iv). The System is the most quoted work in the Principles (14 times). ${ }^{12}$ The first quote can be found in paragraph $\S 100$ titled Preiskampf (price fight):

A very barbarous theory of price in Xenoph. De vectigg. 4. The ancients never made much progress in this respect, although there was no lack of keen observation of individual price processes: compare Aristot. Oecon. II. Cicero De off. III, 12 ff. Mariana De rege et regis institutione (1598) III, 8 explains price by the ratio of value and quantity (Roscher 1864 [1854], 191; emphasis in original).

Roscher does not go into further detail, but proceeds afterwards with price theory in Locke. Basically Roscher would have to be in accordance with Mariana, since he writes in the same paragraph: «The more supply of a commodity outweighs demand, the lower is the price; the more demand outweighs supply, the higher is the price» (Roscher 1864 [1854], 189). The second quote is located in paragraph §114 titled Ausnahmen (exceptions). «Exceptions» refer to situations in which price formation on the unhampered market produces «a disturbance of the total commerce» (Roscher 1864 [1854], 211). Taxes can be a solution to these disturbances which can occur due to «state privileges» (ibid.). Roscher comments in this context on 16th and 17th century thinkers who overly prefer taxes:

The preference for governmental taxes is odd, which the greatest authorities of the 16th and 17th century express, especially the German ones: thus Luther Vom Kaufhandel und Wucher (1524); Calvin (Leben Calvins von Henry, II, supplement 3, p. 23); Bornitz De rerum sufficientia, 1625, p. 246; v. Seckendorff Deutscher Fürsten-

${ }^{12}$ Menger cites the 1857-edition ( 2 times) and the 1868-edition (12 times). We cite the 1864-edition because the 1868-edition was not available. All three quotes are the same in the 1857- and 1864-edition. 
staat (5th ed. 1678), p. 210; Becher II, p. 1823 ff.; Horneck, Oesterreich über Alles, wenn es will (1684), p. 123. Similarly Mariana De rege et regis institutione III, 9. (compare however III, 8) (Roscher 1864 [1854], 212; emphasis in original).

As indicated by the word «odd», Roscher disapproves of the treatment of taxes in Mariana. However, he seems to be more in accordance with their treatment in chapter 8 («compare however III, 8»). The content of this reference is truly odd since Mariana is usually characterized as «learned extremist» (Rothbard 2006 [1995], 117) and «[p]erhaps the most libertarian of all scholastics» (Huerta de Soto 1999, 2). In this passage, the greater extremist and libertarian seems to be Roscher. The last quote can be found in paragraph §231 titled Luxus blühender Zeiten (luxury of prosperous times):

Ad. Smith W. of N. II, Ch. 3 nicely distinguishes luxury in permanent and rapidly perishable goods; the first is less capable of impoverishing the individual or the whole nation, it rather is inclined to thriftiness. Similarly already Isocrates ad Nicocl. p. 19. Livius XXXIV, 7; Plin. H. N. XIII, 4; Mariana (1598) De rege et regis institutione III, 10 (Roscher 1864 [1854], 471-2; emphasis in original).

Roscher approvingly cites Mariana. Roscher (ibid., 471) argues in the main text that consumption will be diverted to "vain», "rapid» and «immoral» needs if wealth is unequally distributed in society. It is in this context where he presents the views of Adam Smith and his predecessors. Lastly, Roscher refers two times to De rege in his history of German economic thought. Both quotes refer to the same chapter and express the same thoughts, therefore we limit ourselves to the first and more extensive quote:

To recall a Spaniard at this point as well, Mariana wants foreign commodities highly taxed so that less money flows out of the country, and so that foreign craftsmen by relocation to Spain increase its welfare at the same time (De rege et regis institutione, 1598, III, 7. 10.) (Roscher 1874, 191; emphasis in original).

This quote is disapproving and again about taxation. Roscher cites Mariana in a passage about mercantilism. Curious is the reference to Mariana's home country Spain. Even Roscher remarks 
that Spanish economic thought is almost absent in his history. In sum, we have two approving and two disapproving quotes. None of them is about subjective value theory, where «our Spanish writers appear to have made their most enduring contribution» (GriceHutchinson 1952, 77).

TABLE 3

\section{GERMAN ECONOMISTS QUOTED IN MENGER'S PRINCIPLES}

\begin{tabular}{|c|c|c|c|}
\hline Author $\left({ }^{*}-t\right)$ & Work(s) cited ${ }^{1}$ & Quotes $^{2}$ & $\begin{array}{l}\text { References } \\
\text { to Spanish } \\
\text { scholastics }\end{array}$ \\
\hline $\begin{array}{l}\text { Wilhelm } \\
\text { Roscher } \\
(1817-1894)\end{array}$ & $\begin{array}{l}\text { System der Volkswirthschaft I (1857, } \\
\text { 1868), Grundriß zu Vorlesungen über } \\
\text { die Staatswirthschaft (1843), Ansichten } \\
\text { der Volkswirthschaft aus dem } \\
\text { geschichtlichen Standpunkte (1861) }\end{array}$ & $17(1)$ & 3 \\
\hline $\begin{array}{c}\text { Albert } \\
\text { Schäffle } \\
(1813-1903)\end{array}$ & $\begin{array}{c}\text { Das gesellschaftliche System der } \\
\text { menschlichen Wirthschaft (1867), Die } \\
\text { ethische Seite der } \\
\text { nationalökonomischen Theorie vom } \\
\text { Werthe (1862)*, Die } \\
\text { nationalökonomische Theorie der } \\
\text { ausschließenden Absatzverhältnisse } \\
\text { (1867) }\end{array}$ & $11(1)$ & 0 \\
\hline $\begin{array}{l}\text { Friedrich von } \\
\text { Hermann } \\
(1797-1868)\end{array}$ & $\begin{array}{c}\text { Staatswirthschaftliche Untersuchungen } \\
\text { über Vermögen, Wirthschaft, } \\
\text { Productivität der Arbeiten, Kapital, } \\
\text { Preis, Gewinn, Einkommen und } \\
\text { Verbrauch (1832) }\end{array}$ & $9(2)$ & 0 \\
\hline $\begin{array}{l}\text { Karl Knies } \\
(1821-1898)\end{array}$ & $\begin{array}{c}\text { Die politische Oekonomie vom } \\
\text { geschichtlichen Standpuncte (1853), Die } \\
\text { nationalökonomische Theorie vom } \\
\text { Werth (1855)*, Ueber die } \\
\text { Geldentwertung und die mit ihr in } \\
\text { Verbindung gebrachten Erscheinungen } \\
(1858)^{*}\end{array}$ & $8(2)$ & 0 \\
\hline $\begin{array}{l}\text { Lorenz von } \\
\quad \text { Stein } \\
(1815-1890)\end{array}$ & $\begin{array}{l}\text { System der Staatswissenschaft I (1852), } \\
\text { Lehrbuch der Volkswirthschaftslehre } \\
\text { (1858) }\end{array}$ & 6 & 0 \\
\hline $\begin{array}{c}\text { Karl Heinrich } \\
\text { Rau } \\
\text { (1792-1870) }\end{array}$ & $\begin{array}{l}\text { Grundsätze der Volkswirthschaftslehre } \\
\text { I }(1826,1863)\end{array}$ & $4(3)$ & 0 \\
\hline
\end{tabular}




\begin{tabular}{|c|c|c|c|}
\hline Author $\left({ }^{*}-t\right)$ & 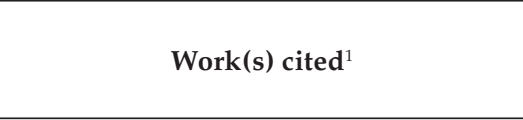 & Quotes $^{2}$ & $\begin{array}{l}\text { References } \\
\text { to Spanish } \\
\text { scholastics }\end{array}$ \\
\hline $\begin{array}{l}\text { Johann F. E. } \\
\text { Lotz } \\
(1771-1838)\end{array}$ & $\begin{array}{l}\text { Handbuch der Staatswirthschaftslehre } \\
\qquad(1837)\end{array}$ & $3(3)$ & 0 \\
\hline $\begin{array}{l}\text { Gottflieb } \\
\text { Hufeland } \\
(1760-1817)\end{array}$ & $\begin{array}{c}\text { Neue Grundlegung der } \\
\text { Staatswirthschaftskunst I/II }(1807,1815)\end{array}$ & 5 & 0 \\
\hline $\begin{array}{l}\text { Bruno } \\
\text { Hildebrand } \\
(1812-1878)\end{array}$ & $\begin{array}{l}\text { Die Nationalökonomie der Gegenwart } \\
\text { und Zukunft (1848), } \\
\text { Naturalwirthschaft, Geldwirthschaft } \\
\text { und Creditwirthschaft (1864)* }\end{array}$ & $4(1)$ & 0 \\
\hline $\begin{array}{l}\text { Hermann } \\
\text { Rösler } \\
(1834-1894) \\
\end{array}$ & $\begin{array}{l}\text { Grundsätze der Volkswirtschaftslehre } \\
(1864), \text { Zur Theorie des Werthes }(1868)^{*} \\
\text { Zur Theorie des Preises }(1869)^{*}\end{array}$ & $4(1)$ & 0 \\
\hline $\begin{array}{l}\text { Julius Graf } \\
\text { von Soden } \\
(1754-1831)\end{array}$ & Die National-Oekonomie I/IV (1805) & 4 & 0 \\
\hline $\begin{array}{l}\text { Hans von } \\
\text { Scheel } \\
(1839-1901)\end{array}$ & $\begin{array}{c}\text { Der Begriff des Geldes in seiner } \\
\text { historisch-ökonomischen Entwicklung } \\
(1866)^{*}\end{array}$ & 3 & 0 \\
\hline $\begin{array}{l}\text { Friedrich } \\
\text { Karl von } \\
\text { Fulda } \\
(1774-1847) \\
\end{array}$ & $\begin{array}{l}\text { Grundsätze der ökonomisch-politischen } \\
\text { oder Kameralwissenschaften (1820) }\end{array}$ & $2(1)$ & 0 \\
\hline $\begin{array}{l}\text { Johann } \\
\text { Adam } \\
\text { Oberndorfer } \\
(1792-1871)\end{array}$ & System der Nationalökonomie (1822) & $2(1)$ & 0 \\
\hline $\begin{array}{c}\text { Otto } \\
\text { Michaelis } \\
(1826-1890) \\
\end{array}$ & $\begin{array}{c}\text { Das Kapitel vom Werthe }(1863)^{*} \text {, Die } \\
\text { wirthschaftliche Rolle des } \\
\text { Spekulationshandels }(1864)^{*} \\
\end{array}$ & 2 & 0 \\
\hline $\begin{array}{c}\text { Johann Georg } \\
\text { Büsch } \\
(1728-1800)\end{array}$ & Abhandlung von dem Geldumlauf II & $1(1)$ & 0 \\
\hline
\end{tabular}

${ }^{13}$ Notes: ${ }^{1}$ Roman letters indicate the volume and numbers in brackets indicate the edition cited by Menger.

13 «Works cited» are ordered according to their number of citations (from high to low). If Menger repeatedly refers to the same book in a passage, it was counted as one quote. Solely Knies is an exception to this rule because Menger referred four times in 
${ }^{2}$ Number in brackets indicate how many times Menger mentioned the author without explicit reference to source material.

*indicates a journal article either published in «Jahrbücher für Nationalökonomie und StatistikÌ (editor: Hildebrand), «Zeitschrift für die gesamte Staatswissenschaft» (editor: Rau) or «Vierteljahrschrift für Volkswirthschaft und Kulturgeschichte» (editor: Julius Faucher).

\section{From where did Hufeland borrow his Subjectivism?}

The crucial question is now: if Gottlieb Hufeland was "the constantly quoted first author on subjective economic concepts in German economics" (Streissler 1990a, 42), by whom was he influenced? May there even be a connection between Hufeland and Say, so that the knowledge of the Spanish scholastics passed from Italy to France, Germany and finally to Austria? Let us begin with the authors cited by Hufeland in the first volume of Neue Grundlegung der Staatswirthschaftskunst (1807). The most quoted author is August Ferdinand Lüder (52 times), followed by Jean Charles de Sismondi (37), Jean-Baptiste Say (30), Adam Smith (26), Johann Georg Büsch (24) and Christian von Schlözer (19). The Germans Lüder, Schlözer and Büsch all defend cost of production or labour theories of value. Lüder writes for example that "labour is therefore the true measure of exchange value of all goods" (Lüder 1800, 65; emphasis in original). Lüder was a pronounced follower of Adam Smith, as indicated by the subtitle of his book Nach Adam Smith bearbeitet (Treated according to Adam Smith).

\footnotetext{
a row to his essay of 1855 , which was counted as two quotes. Before starting the research, we controlled whether the key word search worked for the PDF document. We looked for the following key words (key words are given in brackets): Diego de Covarrubias y Leyva (Cobarrubias, Covarrubias, Covarruvias, Leyva), Martín de Azpilcueta (Aspilcueta, Azpilcueta, Azpilicueta, Navarro, Navarrus, Navarus, Nauarro), Juan de Mariana (Mariana), Luis Saravia de la Calle (Calle, Sarabia, Saravia, Sarravia), Jerónimo Castillo de Bovadilla (Bobadila, Bobadilla, Bovadila, Bovadilla, Castillo), Juan de Lugo (Lugo, Quiroga), Juan de Salas (Gonzalez, Salas), Tomás de Mercado (Mercado), Luis de Molina (Molina), Francisco de Vitoria (Victoria, Vitoria), Domingo de Soto (Dominico, Soto), Juan de Medina (Medina), Francisco Garcia (Garcia), Domingo de Banez de Mondragon (Banez, Mondragon), Francisco Suarez (Suarez), Leonard Lessius (Lessius).
} 
Of all cited scholars, the sole subjectivist economist seems to be Jean-Baptiste Say. He defends a utility theory of value in A Treatise on Political Economy (1803), which came out four years before Hufeland's Grundlegung. Hufeland praises the Treatise in his introduction as «an exact, and in parts own development of the ideas of Adam Smith» which «added some new in detail» (Hufeland 1815 [1807], xiv). This is nothing special since Hufeland praises several authors there, including Adam Smith, but illustrates Say's relevance. Say (1971 [1803], 62) writes about subjective value: «The value that mankind attach to objects originates in the use it can make of them.» Similarly: «the value of products is not founded upon that of productive agency, as some authors have erroneously affirmed; and that since the desire of an object, and consequently its value, originates in its utility, it is the ability to create the utility wherein originates that desire, that gives value to productive agency» (ibid., 287). Let us compare these programmatic statements with Hufeland:

[T]hings which turn into goods (...) may be made of labour for the greatest part, however they do not become goods due to labour, but this solely depends on the imagination of their value, of their suitability as a means to an end which one has and wants to achieve (Hufeland 1815 [1807], 32; emphasis in original).

In our opinion, Hufeland outcompetes Say on subjective value. The French economist does not really stress the essence of subjectivism: that it is only in our mind or «imagination» where value, cost, profit, utility and so on come into existence. Whereas Say mostly argues that value is determined by the use of an object (utility), Hufeland opines that value depends on the imagined use which we create in our minds. Thus we do not read in Say sentences like there is «absolute sovereignty of opinion in the realm of goods and of wealth» (ibid., 19). At one point, Say comes pretty close in expressing the essence of subjective value theory as Hufeland does, when he writes in a kind of inconvenient formulation: «But the point of comparison is variable in amount, according to the degree of estimation in the mind of the valuer» (Say 1971 [1803], 284). But Hufeland stresses this point in many passages in his book (Roscher 1874, 657-8), and not sporadically in a 500-pages volume. 
Even more, Say made a mistake in the presentation of value theory in earlier editions of his Treatise, like he admits in a footnote (Say 1971 [1803], 285). ${ }^{14}$ Hence it is no surprise that Hufeland is not satiesfied with Say and his treatment of value theory. He paraphrases Say with the statement that value and usefulness is not created («geschaffen») but generated («erzeugt») in production. Hufeland (1815 [1807], 33) responds to this: «Even this argument will only appear in its complete power and clarity if one actually considers the fact that the human mind indeed has its own sphere in which it creates something, namely it creates imaginations in itself or in others. $\rangle^{15}$ Hufeland (1815 [1807], 32) also argues that this subjective view has to be constantly applied to economic theory. And he sees his subjectivism as his innovation:

Allow me to expressly remark once again, in consideration of these last two points, that I therein deviate from all previous writers on political economy, namely from Smith and his successors, from $\mathrm{Ca}$ nard, Büsch, Garnier, Say, Simonde and others. Only with regard to the first point Lüder has already noticed a number of certain things belonging to it; the second point [subjectivism] is, however, what causes the greatest alteration of the entire perspective, if it is prop-

14 «In the earlier editions of this work, I had described the measure of value to be the value of the other product, that was the point of comparison, which was incorrect. The quantity and not the value of that other product, is the measure of value in the object of valuation.»

15 «So sinnreich auch zur Rettung der Grundbehauptung desselben, daß alle Güter nur von der Natur herkamen, unter andern von Schmalz gefragt worden ist, 'seit wenn denn das Schaffen nicht mehr aus schließlich in der Macht des Schöpfers sey', und seit wenn 'die Menschen diese Macht mit ihm theilten?' so ist freylich immer hiergegen schon die Bemerkung triftig, daß Hervorbringung in staatswirthschaftlicher Hinsicht keine Schöpfung, sondern nur Erzeugung des Werthes, der Brauchbarkeit sey** [first reference to Say]. Allein selbst dieses Argument wird doch erst dann in seiner vollen Kraft und Klarheit erscheinen, wenn man eben darauf eigentlich sieht, daß der Geist des Menschen allerdings wirklich seine Sphäre hat, in der er etwas schafft, nähmlich wenn er Vorstellungen bey sich und andern erzeugt. Daß dem zu Folge ein Gut Gut, also das wird und ist, worauf hier alles ankommt, macht in der That dieser schaffende Geist allein möglich. Der Mensch kann freylich im andern Sinne so wenig schaffen, als vernichten; aber diese seine Unfähigkeit geht nur den Stoff an.

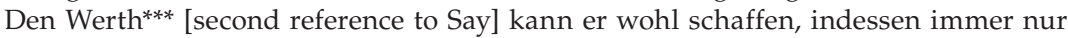
eben darum, weil dieser Werth allezeit ganz von der seiner eigenen Wirkung überlassenen Vorstellung abhängt» (Hufeland 1815 [1807], 33; emphasis in original). 
erly performed and asserted in every aspect (Hufeland (1815 [1807], 32; emphasis in original). ${ }^{16}$

Hufeland (1815 [1807], 15-24) does also not quote anybody in key parts of his section on goods and value - except of Sismondi once but on an unrelated topic. If we consider this together with Steissler's assessment that Hufeland was «the constantly quoted first author on subjective economic concepts» (Streissler 1990a, 42), proving a link to previous economists seems very difficult. In respect to this question, a more profound study is necessary about the origin of subjective value theory in German economics. ${ }^{17}$ In our opinion, there could be another explanation for the subjectivism in the German literature. Wilhelm Roscher hints it in his history of economic thought: «What distinguishes him [Hufeland] from all other Smithians are especially two characteristics: his chief occupation with jurisprudence and his additional occupation with philosophy, particularly the one of his compatriot Kant» (Roscher 1874, 656; emphasis in original). And: «one is most beautifully reminded of Kant with this mental, anti-materialistic sense which Hufeland applies to economics. Everywhere he attaches the greatest weight to

16 «Nur darf immer dabey zweyerley durchaus nicht übersehen werden : 1) daß zwar sehr viele, aber bey weiten doch nicht alle, Mittel durch Arbeit vorhanden seyen oder entstehen, daß mehrere die Natur erzeuge; daß man ohne Uebertreibung sagen könne, die Natur habe an jedem, selbst durch die Arbeit erzeugten Gute Antheil; dann aber auch 2) welches noch viel wichtiger und bedeutender ist - daß die Dinge, welche Güter werden, zu solchen gebraucht werden können, zwar größten Theils durch Arbeit entstehen mögen; daß sie aber durch Arbeit nicht Güter werden, sondern daß dieses nur durch die Vorstellung von ihrem Werthe, von ihrer Tauglichkeit als Mittel zu einem Zwecke, den man hat und erreichen will, abhängt; daß also auch zu dieser Rücksicht auf Gütervermehrung eigentlich vor andern Ursachen Vielheit der Zweckhabenden und Mannigfaltigkeit der Zwecke wirken. Es sey mit erlaubt, in Rücksicht dieser beyden letzten Puncte nochmahls ausdrücklich zu bemerken, daß ich darin von allen bisherigen Schriftstellern über Staatswirthschaft, nahmentlich von Smith und seinen Nachfolgern, von Canard, Busch, Garnier, Say, Simonde u. a. abweiche. Nur in Ansehung des ersten Punctes hat Lüder schon einiges dahin Gehörige bemerkt; der zweyte hingegen ist es eben, welcher in der ganzen Ansicht die größte Umänderung bewirkt, wenn er gehörig durchgeführt und in allen Rücksichten geltend gemacht wird» (Hufeland 1815 [1807], 31-2; emphasis in original).

17 Although Hufeland is «the constantly quoted first author on subjective economic concepts», there are also other German economists who early defended a subjective value theory. Komorzynski $(1889,65)$ names Jacob, Soden, Lotz, Hufeland and Storch. 
the psychic processes which are at the basis of economic facts» (ibid., 657-8; emphasis in original).

Idealistic philosophy and especially Kant might explain Hufeland's subjectivism and its favourable reception by other German economists. Not only because of its mental, anti-materialistic sense. Kantian philosophy tends to view the world as a creature of the mind whose perception is created by certain categories which are imposed over the world. One can therefore not perceive the world as it is objectively, but one's mind always adds or mixes something into the perception of it. Hence perception of the external world is subjectively created in each mind, and perceiving the external world as it is objectively (Ding an sich) is impossible. In this sense, Kantian philosophy rather leads one to interpret concepts like value, cost or profit also as phenomena which are subjectively created in each mind, and not as objectively accessible facts like cost of production or labour.

Kantian philosophy can also explain differences in the geographic diffusion of subjective value theory. It may not be (exclusively) a question of religion, as suggested by Kauder and later Rothbard (2006a [1995], xii), but of epistemology and metaphysics. Karl Brandt $(1992,162)$ writes in the first volume of his history of German economic thought - in which he does not mention the Spanish scholastics - that one difference between German and foreign classical economics is «the influence of idealistic philosophy» in Germany. In England, the intellectual scene was not dominated by idealistic rationalism but by the empiricism of the Scottish Enlightenment. Hence English economists did not stick to subjective valuations but explained value by observable phenomena of the external world, like labour or cost of production. Curiously, Menger (2007 [1871], 307) refers in his Principles to philosophy when he speaks of differences on value theory in Germany and England: «Perhaps nothing reveals the German tendency toward philosophical penetration of economics and the practical sense of the English better than a comparison of the treatments given the theory of value by German and English writers.» The victory of subjectivism in Germany and its decline in England might therefore be the result of two back then prevailing, philosophical paradigms. 
VI

AN INTELLECTUAL BRIDGE ACROSS ITALY?

We already know that Huerta de Soto (2008 [2000], 34) argues that Italy acted «as a cultural bridge across which the intellectual exchange between the far points of the empire (Spain and Austria) flowed.» Similarly, Rothbard (2006c [1976]) opines that Spanish scholasticism influenced Galiani who in turn influenced Condillac and Turgot. Let us see if these viewpoints are backed by citations. We begin with France and walk back in time to Spain. Like GriceHutchinson, we do not find any citations of the Spanish scholastics in Condillac or Turgot. ${ }^{18}$ Condillac's main work on economics is Le Commerce et le gouvernement considérés relativement l'un à l'autre (Commerce and Government Considered in their Mutual Relationship, 1776). Menger cites this book six times in his Principles, including two times on subjective value theory. But Condillac does not cite Galiani in his book. Our second French economist Turgot is cited eight times in the Principles. Menger refers four times to Turgot's magnum opus Réflexions sur la formation et la distribution des richesses (Reflections on the formation and distribution of wealth, 1766). Turgot does also not refer to Galiani. Thus there is no citational evidence that Galiani influenced Condillac or Turgot. Nonetheless it could be that there are quotes of Galiani in other works by them, especially since Grice-Hutchinson $(1952,63)$ seems to have discovered citations.

If we walk a further step into the past, what is with the Italian economists? We made a key word research in all their works cited in the Principles. These are 16 works by 13 economists. The result: three authors quote the Spanish scholastics six times in total. These are the already-known quote in Galiani's Della Moneta (1751), one in Davanzati's Lezioni delle monete (Lessons on coins, 1588) and four in Carli's Dell'origine e del commercio della moneta (On the origin and commerce of money, 1751). Especially Galiani's book is highly important because Menger approvingly cites it on subjective value theory as follows: "In the same spirit [like Aristotle] Ferdinando Galiani (...) writes "ch'essendo varie le disposizioni degli animi

${ }^{18}$ We looked for citations in Condillac's Le commerce and Turgot's Réflexions. 
umani e varj i bisogni, vario è il valor delle cose"» (Menger 2007 [1871], 296). ${ }^{19}$ Menger thus knew Galiani's value theory, and he most likely stumbled over the quote of Covarrubias. Table 4 shows all Italian economists which Menger cites in his Principles. As can be seen, Menger mostly quotes them on the origin of money (18 of 21 quotes). The great majority of citations is approving. Menger only disagrees with four of the 21 quotes. But solely two quotes are about subjective value theory, in Galiani and Montanari. Let us begin with Carli's four quotes of Mariana's De rege. The most interesting citation is probably the following:

Having said that, we can clearly conclude that any arbitrary change of the coin could not ever be made without taking away the commerce or the money from the nation. Then, Doctor Juan de Mariana came to establish with clearness that the king cannot debase the coins without the advice of the nation (Carli 1751, 38; emphasis in original).

Carli approvingly cites Juan de Mariana on the distorting effects of inflation, understood as the debasement of the coinage. The other three quotes are about historical episodes on the Iberian Peninsula during which the king debased coins. One example is King Alfonso XI of Castile in the 14th century. He replaced old by new coins which led to higher food prices and a famine (Carli 1751, 53). The next Italian author is Davanzati who cites Covarrubias:

To sum up, the national mint would like to render the same coined metal that it receives for coining. Thus, would the mint put a part of its own in the expense? Never, since many people think by common sense that this expense should be paid by the town hall [reference to Covarrubias] in order to keep the blood in the republic (Davanzati 1804 [1588], 46).

«[T]o keep the blood in the republic» could also be translated with «to keep the republic alive.» The quote basically says that government should absorb costs of the coinage. The footnote in which

19 «since the dispositions of human minds vary, the value of things varies» (Menger 2007 [1871], 296). 
Covarrubias is mentioned states: «This opinion was based on Bart. in 1. I ff. de vet. num. potest. lib. II contr. Innoc. Look also Couvarruv. veter. collat. numism. cap. 7 n. 5. Id.» (ibid., emphasis in original). Lastly, we come to the Covarrubias-quote in chapter two of Della Moneta - a chapter about value theory. Galiani begins this chapter with criticizing Aristotle's theory of the origin of money. Afterwards he writes:

Then it is clear how the bishop Covarrubias keeps following his master [Aristotle] by stating: If coins receive value not from nature itself but from the prince, and because of him the laws recalled can become useless, certainly, the material is judged not to be worth of gold or silver; although if it was judged by the very nature it would not have a value by law; and the Aristotelians, of which the whole corps of Jurists and Moralists is basically composed, think the same way. If this basis it is true, it is quite clear the truthfulness of these consequences. But in case they are deadly and cause pain and sorrow for the population, I would not like to see this to be demonstrated by the very experience (Galiani 1803 [1751], 56; emphasis in original).

Covarrubias argues that "coins receive value not from nature itself but from the prince». Galiani does not agree with Aristotle and Covarrubias. He argues in chapter one that the value of money is determined by the use value of gold and silver (Giocoli 2001, 98). Covarrubias defends here the old medieval view which GriceHutchinson $(1952,31)$ calls «nominalism». As we saw before, the Spanish scholastics had already applied their subjective value theory on money. But Galiani does not cite or acknowledge their theoretical improvements. Either way, Galiani concludes the following:

For this reason, before anyone else, I will do anything to show, thanks to all my studies, what I have been convinced about since a long time, the fact that not only the metals that compose the coin but everything else in the world, with no exception, has its own value starting from certain general and constant principles; that neither whim, nor law nor prince nor anything else can destroy these principles and their effect; and finally, that in the estimate men, as the scholastics say, are passive se habent (Galiani 1803 [1751], 57; emphasis in original). 
Thus Galiani cites Covarrubias disapprovingly. Curiously, Menger -who writes that Covarrubias did not improve on the origin of money in comparison to Aristotle-cites Covarrubias on the same topic. Again this raises the question why there seems to be no approving citation of Covarrubias on value theory. Either Galiani was not aware of the subjectivist contributions of the Spanish scholastics. This would point to what Hülsmann $(2007,112)$ comments: that their "discoveries about the nature of value and prices were scattered across thousands of pages.» Or he knew of their subjectivist discoveries, since it is unlikely that Abbé Galiani was not familiar with the literature on moral theology. Rothbard (2006 [1976]) stresses this point cogently: «Galiani's uncle Celestino, who brought up the youthful economist, had been professor of moral theology before becoming an archbishop and was therefore undoubtedly familiar with the Scholastic literature on the subject, which filled the Italian libraries of the eighteenth century.» And Grice-Hutchinson $(1952,76)$ writes:

The most serious objection to the version of events just put forward is the fact that Condillac, Turgot, and Galiani all asserted that their own emphasis on utility and rarity was a novelty. All three writers were noted for their learning, especially in theology and jurisprudence. It is hard to believe that they had not read any of the books referred to above. As eighteenth-century philosophes they might perhaps have felt reluctant to acknowledge their debt to the casuists. But any such reluctance could not have extended to Grotius, Pufendorf, or Hutcheson. I can only suppose that Galiani came across the essential element of this theory of value in the work of some earlier author, and that the wit and grace with which he expressed these old truths made them seem like innovations to his contemporaries. However this may be, the existence of a subjective theory of value in the work of our Spanish writers and their successors may well have paved the way for the favourable reception that was at once accorded to Galiani's great masterpiece..$^{20}$

${ }^{20}$ Roover $(1974,334)$ agrees with Grice-Hutchinson: «The question arises whether this idea originates with the two abbés [Condillac and Galiani] or whether —what is more likely - they took it from the Doctors, possibly by way of late casuists and the school of Salamanca, as Marjorie Grice-Hutchinson seems to think [in her book The School of Salamanca]. In my opinion, she is undoubtedly right, since it is highly improb- 
Certainly, Grice-Hutchinson and Rothbard make some reasonable arguments why Galiani could have borrowed from the (Spanish) scholastics. Roover $(1974,319)$ observes about the 18th century Philosophes to which Galiani, Turgot and Condillac belonged: «Whenever the Philosophes refer to the Doctors, they call them "casuists" with an undertone of scorn and contempt. They refer to them only to criticize; and when they borrow from them, they do not give them any credit.» He furthermore shows that Turgot and Condillac participated in this attack against the Doctors (Roover 1974, 319-20). But although it is possible that Galiani borrowed, at the end we can just speculate on this point. There is no hard evidence - like for the German economists and Mengerthat Galiani took up the value doctrine of the (Spanish) scholastics. It could as well be that he discovered the subjective theory on his own before he consulted the scholastic literature. Or maybe he did not borrow from the Spanish scholastics, but from the Italian or the medieval scholastics.

And in fact, even if Galiani would praise the Spanish value theory, there would still remain doubt concerning his influence on subsequent economists. Joseph Schumpeter (1994 [1954], 302) agrees with Rothbard and Grice-Hutchinson that Galiani «anticipated the value theory of the next hundred years (...).» But what kind of value theory does he mean? The kind of value theory we find in Condillac, Say or Hufeland? No, he mentions three other names: «Ricardo and Marx» and «A. Smith». Schumpeter detects a subjective and a labour value theory in chapter two of Della Moneta (ibid., 300-2). He is not the only historian —Giocoli (2001, 96) speaks of «some interpreters» who share this opinion. On one side, Galiani first defines value as subjective: «the value of things varies as men's ideas and needs vary» (Galiani 1803 [1751], 58). But then he suddenly claims:

able that cultured men in holy orders would be unacquainted with the extensive literature on moral theology. As far as Galiani is concerned, scholastic influence is noticeable in many passages of his essay on money, especially in his treatment of usury and cambio. Furthermore, the chapter on value contains a citation from Diego de Covarrubias y Leyva, one of the leading representatives of the school of Salamanca. Consequently, Galiani knew his work and there was no breach of continuity.» 
I turn next to the discussion of labour. This alone gives things value whether they are entirely works of art, such as paintings, sculptures, carvings, et cetera, or such things as minerals, stones, wild fruit trees, and so on. The quantity of the material in these bodies contributes to value in no other manner except that it increases or reduces work (Galiani 1803 [1751], 74-5).

This passage appears like a grave contradiction. In his research, Giocoli $(2001,132)$ nevertheless concludes that «it is not possible anymore to view Galiani also as a forerunner of the labor theory of value.» For us, it is not so important what Galiani ultimately meant to say. We just have to note that there was confusion on his presentation of value theory. Thus Della Moneta may have also spread the labour theory of value. Curiously, Karl Marx himself cites Galiani in a footnote of $A$ Contribution to the Critique of Political Economy (1859):

See e.g. Galiani, in vol. 3 of «Della Moneta,» Scrittori Classici italiani di Economia politica (Published by Custodi). Parte Moderna, Milano, 1803. «La fatica, he says, è l'unica cosa che dà valore alla cosa» («only effort can give value to any thing»). The designation of labor as «fatica,» strain, effort, is characteristic of the southerner (Marx 1903 [1859], 65).

In the main text, Marx writes that some Italian economists "came close to a correct analysis of the nature of commodity" (ibid.). Thus in sum, we do not find much citational evidence for a link between Covarrubias, Galiani, Condillac and Turgot or for an intellectual bridge across Italy.

TABLE 4

ITALIAN ECONOMISTS QUOTED IN MENGER'S PRINCIPLES

\begin{tabular}{|c|c|c|c|c|}
\hline Author $\left(^{*}, \mathbf{t}\right)$ & Work(s) cited ${ }^{1}$ & Topic of the quote & Quotes & $\begin{array}{c}\text { References } \\
\text { to Spanish } \\
\text { scholastics }\end{array}$ \\
\hline $\begin{array}{c}\text { Geminiano } \\
\text { Montanari } \\
(1633-1687)\end{array}$ & Della moneta III & $\begin{array}{c}\text { Origin of money*, } \\
\text { Subjective value } \\
\text { theory, Price theory* }\end{array}$ & 3 & 0 \\
\hline $\begin{array}{c}\text { Antonio } \\
\text { Genovesi } \\
(1712-1769)\end{array}$ & $\begin{array}{c}\text { Lezioni di } \\
\text { commercio o sia } \\
\text { d'economia civile }^{\prime}\end{array}$ & $\begin{array}{c}\text { Origin of money (2), } \\
\text { Definition of the term } \\
\text { good }^{*}\end{array}$ & 3 & 0 \\
\hline
\end{tabular}




\begin{tabular}{|c|c|c|c|c|}
\hline Author $\left({ }^{*}, \mathbf{t}\right)$ & 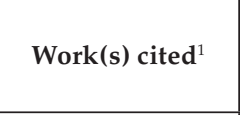 & Topic of the quote & Quotes & $\begin{array}{l}\text { References } \\
\text { to Spanish } \\
\text { scholastics }\end{array}$ \\
\hline $\begin{array}{l}\text { Ferdinando } \\
\text { Galiani } \\
(1728-1787)\end{array}$ & $\begin{array}{c}\text { Della moneta I/II } \\
(1750,1780,1831)\end{array}$ & $\begin{array}{l}\text { Subjective value } \\
\text { theory, Origin of } \\
\text { money }\end{array}$ & 2 & 1 \\
\hline $\begin{array}{l}\text { Giammaria } \\
\text { Ortes } \\
(1713-1790)\end{array}$ & $\begin{array}{c}\text { Della economia } \\
\text { nazionale, Lettere } \\
\text { Di Giammaria } \\
\text { Ortes in } \\
\text { Proposito del Suo } \\
\text { Libro Della } \\
\text { Economia } \\
\text { Nazionale XVI }\end{array}$ & Origin of money & 2 & 0 \\
\hline $\begin{array}{c}\text { Pietro Verri } \\
(1728-1797)\end{array}$ & $\begin{array}{c}\text { Meditazioni sulla } \\
\text { economia } \\
\text { politica, } \\
\text { Riflessioni sulle } \\
\text { leggi vincolanti }\end{array}$ & Origin of money & 2 & 0 \\
\hline $\begin{array}{l}\text { Giovanni } \\
\text { Battista } \\
\text { Corniani } \\
(1742-1813)\end{array}$ & $\begin{array}{l}\text { Riflessioni sulle } \\
\text { monete III, } \\
\text { Lettera ad un } \\
\text { legislatore }\end{array}$ & Origin of money & 2 & $\begin{array}{c}\text { Works were } \\
\text { not } \\
\text { available }\end{array}$ \\
\hline $\begin{array}{c}\text { Bernardo } \\
\text { Davanzati } \\
(1529-1606) \\
\end{array}$ & $\begin{array}{l}\text { Lezioni delle } \\
\text { monete (1588) }\end{array}$ & Origin of money* & 1 & 1 \\
\hline $\begin{array}{l}\text { Gian Rinaldo } \\
\text { Carli (1720- } \\
\text { 1795) }\end{array}$ & $\begin{array}{l}\text { Dell'origine e del } \\
\text { commercio della } \\
\text { moneta }\end{array}$ & Origin of money & 1 & 4 \\
\hline $\begin{array}{l}\text { Sallustio } \\
\text { Bandini } \\
(1677-1760)\end{array}$ & $\begin{array}{c}\text { Discorso } \\
\text { economico (1787) }\end{array}$ & Origin of money & 1 & 0 \\
\hline $\begin{array}{c}\text { Pompeo Neri } \\
(1706-1776)\end{array}$ & $\begin{array}{l}\text { Osservazioni } \\
\text { sopra il prezzo } \\
\text { legale delle } \\
\text { monete (1751) }\end{array}$ & Origin of money & 1 & 0 \\
\hline $\begin{array}{l}\text { Carlo Antonio } \\
\text { Broggia } \\
(1698-1767)\end{array}$ & $\begin{array}{c}\text { Trattato } \\
\text { de'tributi, delle } \\
\text { monete e del } \\
\text { governo politico } \\
\text { della sanita (1743) }\end{array}$ & Origin of money & 1 & 0 \\
\hline
\end{tabular}




\begin{tabular}{|c|c|c|c|c|}
\hline Author $\left(^{*}, \mathbf{t}\right)$ & Work(s) cited $^{1}$ & Topic of the quote & Quotes & $\begin{array}{c}\text { References } \\
\text { to Spanish } \\
\text { scholastics }\end{array}$ \\
\hline $\begin{array}{c}\text { Melchiorre } \\
\text { Gioja (1767- } \\
1829)\end{array}$ & $\begin{array}{c}\text { Nuovo prospetto } \\
\text { delle scienze } \\
\text { economiche I } \\
(1815)\end{array}$ & Origin of money & 1 & 0 \\
\hline $\begin{array}{c}\text { Cesare Beccaria } \\
(1738-1794)\end{array}$ & $\begin{array}{c}\text { Elementi di } \\
\text { economia } \\
\text { pubblica II }\end{array}$ & Origin of money & 1 & 0 \\
\hline
\end{tabular}

Notes: ${ }^{1}$ Roman letters indicate the volume and numbers in brackets indicate the edition cited by Menger.

*indicates that Menger disapprovingly quotes the author.

VII

\section{CONCLUSION}

Did the Spanish scholastics influence Carl Menger in terms of the history of ideas? The evidence we found says no. The following list summarizes the main results:

1) One quote of the Spanish scholastics in Menger's writings (Covarrubias).

2) Two books in the Carl Menger Collection (Molina and Covarrubias).

3) Roscher quotes the Spanish scholastics three times (Mariana) - of all German economists cited in the Principles at least two times.

4) Little evidence that Hufeland was influenced by Say on value theory.

5) Galiani quotes the Spanish scholastics 1 time on value theory (Covarrubias) - of twelve of the 13 Italian economists quoted in the Principles.

Hence we virtually found no evidence that the Spanish scholastics directly influenced Menger, that they influenced the Germans who influenced Menger, or that they influenced the Italians who 
influenced Menger. There is also little evidence for Rothbard's scholastic link from Galiani to Condillac and Turgot, and then to Say:

1) Condillac and Turgot do not cite Galiani or the Spanish scholastics in their main works Le Commerce et le gouvernement and Réflexions.

2) Galiani cites Covarrubias disapprovingly on the value of money in Della Moneta.

3) Galiani's presentation of value theory is ambiguous.

As said, we should be cautious with some of the results since our method of key word researching may not have appropriately worked. Either way, there are still other reasons why the Spanish scholastics should not be considered the originators or the forerunners of Menger's thought. First, anybody who defends the thesis of a Spanish origin must answer the question why we should choose Spain as the prime origin of Menger's thought. During the High Middle Ages, many scholastics had already turned to a quite subjective theory of value (Rothbard 2006c [1976]). Thomas Aquinas writes in his Summa Theologiae (1265-73): «The price of things saleable does not depend on their degree of nature, since at times a horse fetches a higher price than a slave; but it depends on their usefulness to man» (Casey 2010). And even more clearly Jean Buridan (1300-58):

«the value of goods is estimated by human want ... and therefore the satisfaction of want is the real measure of saleable goods. But it would seem that this satisfaction is measured by want itself; for the satisfaction is greater when the want satisfied is great ... as is shown by the fact that wine is dearer when it is scarce, because we need it more» (Grice-Hutchinson 1952, 27).

Buridan seems to have been quite far on value theory. He does not only speak of «human want» determining the value, but also brings in scarcity as a factor of price determination. Against this background, let us look again on the full quote of Covarrubias:

First of all, regarding the case of contracts of purchase and sale and similar contracts of exchange, we must not pay attention nor 
believe that the fair price derives from the nature of the object, but from the assessment of humans, even if such assessment may be unsound: for if the nature of the object were to be observed, a horse would be valued more than a precious jewel on account of the usefulness of the horse, and because everything that has life and breath is, by its very nature, of more worth than that which is dead and lifeless, as Conrad [Summenhart von Calw] supposes in his «Treaty on Contracts», on item 56.2. Thus, among people in India, wheat sells for a greater price than in Spain, at least when its common valuation among men is considered, and not the intrinsic nature of the thing itself, which is the same amongst Spaniards and Indians (Covarrubias [1556] 1661, 122; own emphasis and translation).

The part in italics shows that Covarrubias has objective traces in his take on value. Even more, compare this quote with Buridan and the question arises how much Covarrubias really improved upon value theory. ${ }^{21}$ Another objection against a Spanish-Austrian link is the possibility of a scholastic influence which solely flowed over Italy. Roover $(1974,327)$ notes: «As in Spain, so also in Italy the scholastic traditions were particularly strong, and persisted well into the eighteenth century (...).» Italian economists also seem to be far more cited in the German or Austrian literature than their Spanish colleagues. Of the 13 Italian economists cited in the Principles, Roscher (1874, 1049-62) cites eight economists 15 times in his history of German thought, whereas Spanish economic thought is almost non-present there. Books translated from or published in Italian make up 3.57 percent of the Carl Menger Collection (575 books), whereas Spanish literature only accounts for 0.19 percent (31 books) and Spanish scholasticism for 0.01 percent (2 books). It may therefore be that the Spanish scholastics played no role in transmitting the scholastic value doctrine, although they advanced scholastic economic thought to its highest level.

${ }^{21}$ Roque Sampedro pointed out to the author that Covarrubias takes up a Thomist metaphysical position when he writes: «everything that has life and breath is, by its very nature, of more worth than that which is dead and lifeless.» But even when we disregard this passage, there still remains the comparison between the jewel and the horse. 
Furthermore, the Spanish scholastics never anticipated the real Mengerian achievement due to a missing understanding of marginalism. His achievement was not the recognition that value is subjective. As Schumpeter (2003 [1952], 83) points out: «it can be demonstrated that almost every one of the classical economists tried to start with this recognition and then threw it aside because he could make no progress with it (...).» The achievement of Menger (and the German economists) was to build a general theory which tried to explain all economic phenomena on the grounds of subjective value (ibid.). The Spanish scholastics, in contrast, never achieved more than loosely expressing the content of some modern economic insights. In this sense, Schumpeter points out:

The intellectual achievement of an analyst does not consist in the content of the statement which expresses the fundamental principle, but in his knowing how to make it fertile and how to derive from it all the problems of the science concerned (ibid.). ${ }^{22}$

Hence it is no surprise that the Spanish scholastics never arrived at a price or capital theory which they embedded into a consistent, interdependent theoretical framework. Or like Hülsmann $(2007,112)$ puts it: «the Spanish late-scholastics never produced a treatise on economics, and their discoveries about the nature of value and prices were scattered across thousands of pages.» Finally, if it is true that German economics is the prime influence on Menger, the Austrian school may be more influenced by Adam Smith than many of its leading exponents like to admit today. It is well-known that Menger (1985 [1883], 49) called Adam Smith «the great founder of our science» and that he was intimately familiar with his Wealth of Nations. Streissler (1990b, 111) concludes on Menger's lectures to the crown prince Rudolf: «It is evident from the lecture that Menger had fully absorbed Smith's line of thought, which argues that he had studied Smith closely long before he gave the lectures at short notice to the crown prince [in 1876]. ${ }^{23}$

\footnotetext{
${ }^{22}$ Christian Schneider drew my attention to this quote.

${ }^{23}$ Elsewhere, Streissler $(1994,8)$ goes as far as to trenchantly call the Wealth of $\mathrm{Na}$ tions Menger's «bible».
} 
Further proof for Adam Smith's importance comes from the finding that Menger owned 20 (!) different editions of the Wealth of $\mathrm{Na}$ tions. Without Streissler's research, one might dismiss these editions as a strange curiosity. But put into the above context, they illustrate that Menger was most likely a pronounced follower and maybe even an admirer of Smith. And if this is true, Menger saw himself as part of a tradition which rather goes back to Smith and not the scholastics. Even more, German economics was considerably influenced by Adam Smith as well (Streissler 1990b, 128-9; Brandt 1992, 160; Schumpeter 1994 [1954], 503). As Schumpeter (ibid.) writes:

Smithianism, increasingly leavened with a little (often misunderstood) Ricardo and relieved of some of the older stuff about eighteenth-century administrative policy-this is the formula that characterizes German economics until and even a little beyond the end of the period under survey [1790-1870]. ${ }^{24}$

Thus it is better to interpret the Spanish scholastics, at least for now, not as the forerunners or the origin of the Austrian school -because that invokes this unproven notion of the Doctors influencing Menger-but as its anticipators.

\section{REFERENCES}

Álvarez, Á. M. F. (2015): «Juan de Mariana. Transmisión de las ideas de economía política de España hacia Inglaterra en el siglo XVII.» Iberian Journal of the History of Economic Thought 2 (2): 32-59.

\footnotetext{
${ }^{24}$ At this point, a possibility for future research opens up. This work focused on the continental tradition because Grice-Hutchinson, Huerta de Soto and Rothbard argue for a transmission via the Italian and French economists. Future research could investigate the English tradition and its influence on Menger. Rivas (2013, 83-94) reasons that Adam Smith received a scholastic influence via Grotius, Pufendorf and Hutcheson, but arrives - like Rothbard - at the conclusion that Smith did not adopt the subjective value theory which was present in some scholastic works (ibid., 87-8). Nevertheless, other parts of the Spanish scholastic doctrine could have been transmitted via the English tradition. See also Álvarez (2015) who argues that John Locke received an influence from Juan de Mariana.
} 
BÖHM-BAWERK, E. v. (1890 [1884]): Capital and Interest. A Critical History of Economic Theory. London: Macmillan and Co.

BRANDT, K. (1992): Geschichte der deutschen Volkswirtschaftslehre. Band 1: Von der Scholastik bis zur klassischen Nationalökonomie. Freiburg: Rudolf Haufe Verlag.

BRAUN, E. (2016): «The German historical school on the impossibility of economic calculation under socialism.» Betriebswirtschaftliche Forschung und Praxis 68 (2): 126-135.

CARLI, G. R. (1751): Dell'Origina e del Commercio della Moneta e dell Instituzione della Zecche d'Italia. All'Haja.

CASEY, G. (2010): The Major Contributions of the Scholastics to Economics. Mises Daily. https://mises.org/library/major-contributions-scholastics-economics, last access on 14/10/2016.

Chafuen, A. (1991 [1986]): Economía y Ética. Raíces cristianas de la economía de libre mercado. Madrid: Ediciones Rialp, S. A.

CovarruBiAs y LeYva, D. D. (1661 [1556]): Opera omnia. Lugdunum: Boissat. http://reader.digitale-sammlungen.de/de/fs1/object/display/bsb10796622_00131.html, last access on 14/10/2016.

DavanZATI (1804 [1588]): «Lezioni delle monete.» in: Anton Maria Salvini (ed.). 1804. Scrittori classici italiani de economia politica. Parte antica. Tomo II. Milan: Nella Stamperia e Fonderia di G. G. Destefanis: 19-50.

Gabriel, A. (2012): «Why was the Reception of the First Edition of Mises's Theory of Money and Credit so Lukewarm?» in: Jörg Guido Hülsmann (ed.). The Theory of Money and Fiduciary Media. Auburn: Ludwig von Mises Institute: 37-61.

Galiani, F. (1803 [1751]): «Della Moneta.» in: Anton Maria Salvini (ed.). 1804. Scrittori classici italiani de economia politica. Parte moderna. Tomo III. Milan: Nella Stamperia e Fonderia di G. G. Destefanis: 23-318.

GIOCoLI, N. (2001): «Value and Interest in Ferdinando Galiani's “Della Moneta".» History of Economic Ideas 9 (3): 95-135.

Grice-Hutchinson, M. (1952): The School of Salamanca. Readings in Spanish Monetary Theory 1544-1605. Oxford: At the Clarendon Press.

- (1978): Early Economic Thought in Spain 1177-1740. London: George Allen \& Unwin.

— (1998): «Una nota sobre la difusión del pensamiento económico salmantino.» in: Francisco Gómez Camacho/Ricardo Robledo 
(ed.). El pensamiento económico en la escuela de Salamanca. Una visión multidisciplinar. Salamanca: Ediciones Universidad de Salamanca: 241-8.

HERMANN, F. v. (1832): Staatswirthschaftliche Untersuchungen über Vermögen, Wirthschaft, Productivität der Arbeiten, Kapital, Preis, Gewinn, Einkommen und Verbrauch. München: In der Anton Werber'schen Buchhandlung.

- (1874): Staatswirthschaftliche Untersuchungen. Second Edition. München: Adolf Ackermann.

Hildebrand, B. (1848): Die Nationalökonomie der Gegenwart und Zukunft. First Volume. Frankfurt am Main: Literarische Anstalt.

Hitotsubashi University (2016a): Luis de Molina in Carl Menger Collection. https://opac.lib.hit-u.ac.jp/opac/opac_details/?lang= $1 \&$ bibid $=0000381801$, last access on 14/10/2016.

- (2016b): Diego de Covarrubias y Leyva in Carl Menger Collection. https://opac.lib.hit-u.ac.jp/opac/opac_details/?lang=1\&bib $\mathrm{id}=0000388879$, last access on 14/10/2016.

Hülsmann, J. G. (2007): Mises. The Last Knight of Liberalism. Alabama: Ludwig von Mises Institute.

Huerta De Soto, Jesús (1999): «Juan de Mariana: The Influence of the Spanish Scholastics.» in: Randall G. Holcombe (ed.). 15 Great Austrian Economists. Alabama: Ludwig von Mises Institute: $1-12$.

- (2008 [2000]): The Austrian School. Market Order and Creativity. Cheltenham: Edward Elgar.

- (2009a [1997]): «Interview: the Spanish roots of the Austrian School.» in: Jesús Huerta de Soto (ed.). The Theory of Dynamic Efficiency. New York: Routledge: 263-275.

- (2009b [1999]): «Juan de Mariana and the Spanish Scholastics.» in: Jesús Huerta de Soto (ed.). The Theory of Dynamic Efficiency. New York: Routledge: 204-10.

- (2010 [2009]): Four Hundred Years of Dynamic Efficiency. Mises Daily. https://mises.org/library/four-hundred-years-dynamic-efficiency, last access on 14/10/2016.

Hufeland, G. (1815 [1807]): Neue Grundlegung der Staatswirthschaftskunst durch Prüfung und Berichtigung ihrer Hauptbegriffe von Gut, Werth, Preis, Geld und Volksvermögen mit ununterbro- 
chener Rücksicht auf die bisherigen Systeme. Erster Band. Wien: Bauer.

KNIES, K. (1855): «Die nationalökonomische Lehre vom Werth.» Zeitschrift für die gesamte Staatswissenschaft 11 (3/4): 421-475.

- (1883): Die politische Oekonomie vom geschichtlichen Standpuncte. Braunschweig: C. A. Schwetschke und Sohn.

Komorzynski, J. v. (1889): Der Werth in der isolierten Wirthschaft. Wien: Manz'sche Hof-, Verlags- und Universitätsbuchhandlung.

LÜDER, A. F. (1800): Ueber Nationalindustrie und Staatswirthschaft.

Nach Adam Smith bearbeitet. Erster Theil. Berlin: Heinrich Frölich.

Mangoldt, H. v. (1863): Grundriß der Volkswirthschaftslehre. Ein Leitfaden für Vorlesungen an Hochschulen und das Privatstudium. Stuttgart: Verlag von J. Engelhorn.

MARx, K. (1903 [1859]): A Contribution to the Critique of Political Economy. Chicago: Charles H. Kerr \& Company.

- (1909 [1867]): Capital. A Critique of Political Economy. Volume 1. Chicago: Charles H. Kerr \& Company.

Menger, C. (1871): Grundsätze der Volkswirthschaftslehre. Wien: Wilhelm Braumüller Hof- und Universitätsbuchhändler.

— (1985 [1883]): Investigations into the Method of the Social Sciences. New York: New York University Press.

- (2007 [1871]): Principles of Economics. Alabama: Ludwig von Mises Institute.

Mischler, P. (1857): Grundsätze der National-Oekonomie. Wien: Verlag von Friedrich Manz.

Mises, L. v. (1922): Die Gemeinwirtschaft. Untersuchungen über den Sozialismus. Jena: Verlag von Gustav Fischer.

— (1990 [1962]): «Epistemological Relativism in the Sciences of Human Action.» in: Richard M. Ebeling (ed.). Money, Method, and the Market Process. Norwell: Kluwer Academic Publishers: 37-51.

Rivas, L. G. (2013): «Adam Smith: algunos antecedentes olvidados.» Procesos de Mercado 10 (2): 73-98.

Roover, R. D. (1974): «Scholastic Economics: Surviving and Lasting Influence from the Sixteenth century to Adam Smith.» in: Julius Kirshner (ed.). Business, Banking, and Economic Thought 
in Late Medieval and Early Modern Europe. Chicago: The University of Chicago Press: 306-335.

Roscher, W. (1843): Grundriß zu Vorlesungen über die Staatswirthschaft. Nach geschichtlicher Methode. Göttingen: Druck und Verlag der Dieterichschen Buchhandlung.

- (1864 [1854]): System der Volkswirthschaft. Ein Hand- und Lesebuch für Geschäftsmänner und Studierende. Band I. Fifth Edition. Stuttgart: Verlag der J. G. Gottaschen Buchhandlung.

- (1874): Geschichte der National-Oekonomik in Deutschland. München: R. Oldenburg.

- (1897 [1854]): System der Volkswirthschaft. Ein Hand- und Lesebuch für Geschäftsmänner und Studierende. Band I. Twenty-Second Edition. Stuttgart: Verlag der J. G. Gottaschen Buchhandlung.

RothbARD, M. (2006a [1995]): Economic Thought before Adam Smith. An Austrian Perspective on the History of Economic Thought. Volume I. Alabama: Ludwig von Mises Institute.

- (2006b [1995]): Classical Economics. An Austrian Perspective on the History of Economic Thought. Volume II. Alabama: Ludwig von Mises Institute.

- (2006c [1976]): New Light on the Prehistory of the Austrian School. http://mises.org/library/new-light-prehistory-austrianschool, last access 14/10/2016.

SAY, J. B. (1971 [1803]): A Treatise on Political Economy. Or the Production, Distribution and Consumption of Wealth. New York: August M. Kelley Publishers.

SCHÄFfLE, A. (1867): Das gesellschaftliche System der menschlichen Wirthschaft. Ein Lehr- und Handbuch der Nationalökonomie für alle höhere Unterrichtsanstalten und Gebildete jedes Standes. Second edition. Tübingen: Verlag der H. Laupp'schen Buchhandlung.

- (1870): Kapitalismus und Socialismus mit besonderer Rücksicht auf Geschäfts- und Vermögensformen. Tübingen: Verlag der $\mathrm{H}$. Laupp'schen Buchhandlung.

SCHÜlLER, R. (1899): Die Wirthschaftspolitik der Historischen Schule. Berlin: Carl Heymanns Verlag.

ScHÜZ, K. W. (1843): Grundsätze der National-Oeconomie. Tübingen: Druck und Verlag von C. S. Osiander. 
SchUlaK, E. M./ UnTERKÖFleR, H. (2011): The Austrian School of Economics. A History of Its Ideas, Ambassadors, and Institutions. Alabama: Ludwig von Mises Institute.

SCHUMPETER, J. (1994 [1954]): History of Economic Analysis. London: Routledge.

- (2003 [1952]): Ten Great Economists. From Marx to Keynes. Taylor \& Francis e-Library.

SteIN, L. v. (1858): Lehrbuch der Volkswirthschaft. Zum Gebrauche für Vorlesungen und das Selbststudium. Wien: Wilhelm Braumüller Hofbuchhändler.

StReISSLER, E. (1989): «Der Unternehmer in der deutschen Nationalökonomie des 19. Jahrhunderts.» in: Bernhard Gahlen/ Bernd Meyer/ Jochen Schumann (ed.). Wirtschaftswachstum, Strukturwandel, und dynamischer Wettbewerb. Berlin: Springer-Verlag: 1733.

- (1990a): «The influence of German economics on the work of Menger and Marshall.» in: Bruce J. Caldwell (ed.). Carl Menger and his Legacy in Economics. Durham: Duke University Press: 3168.

- (1990b): «Carl Menger on economic policy: the lectures to Crown Prince Rudolf.» in: Bruce J. Caldwell (ed.). Carl Menger and his Legacy in Economics. Durham: Duke University Press: 107-130.

- (1994): Carl Menger's Lectures to Crown Prince Rudolf of Austria. Cheltenham: Edward Elgar Publishing Unlimited.

— (1997): «Carl Menger, der deutsche Nationalökonom.» in: Birger P. Priddat (ed.). Wert, Meinung, Bedeutung. Die Tradition der subjektiven Wertlehre in der deutschen Nationalökonomie vor Menger. Marburg: Metropolis Verlag: 33-88.

WinKel, H. (1977): Die deutsche Nationalökonomie im 19. Jahrhundert. Darmstadt: Wissenschaftliche Buchgesellschaft.

YAGI, K. (2011): Austrian and German Economic Thought. From Subjectivism to Social Evolution. London: Routledge. 
